Article

\title{
Synthesis, Characterization, Solution Behavior and Theoretical Studies of Pd(II) Allyl Complexes with 2-Phenyl-3H-indoles as Ligands
}

\author{
Maria Tomé ${ }^{1}$, Arnald Grabulosa ${ }^{1} \mathbb{1}$, Mercè Rocamora ${ }^{1}$, Gabriel Aullón ${ }^{1,2}$, Mercè Font-Bardía ${ }^{3}$, \\ Teresa Calvet ${ }^{4}$ and Concepción López ${ }^{1, *(1)}$ \\ 1 Secció de Química Inorgànica, Departament de Química Inorgànica i Orgànica, Universitat de Barcelona, \\ Martí i Franquès 1-11, E-08028 Barcelona, Spain; maria.tome@ub.edu (M.T.); \\ arnald.grabulosa@qi.ub.es (A.G.); merce.rocamora@qi.ub.es (M.R.); gabriel.aullon@qi.ub.edu (G.A.) \\ 2 Institut de Química Teòrica i Computacional, Universitat de Barcelona. Martí i Franquès 1-11, \\ E-08028 Barcelona, Spain \\ 3 Unitat de Difracció de Raigs-X, Centre Científics i Tecnològics (CCiT) Universitat de Barcelona, Solé i Sabaris \\ 1-3, E-08028 Barcelona, Spain; mercef@ccit.ub.edu \\ 4 Department de Cristal-lografia, Mineralogia i Dipòsits Minerals, Facultat de Geologia, Universitat de \\ Barcelona, Martí i Franqués s/n, E-08028 Barcelona, Spain; mtcalvet@ub.edu \\ * Correspondence: conchi.lopez@qi.ub.es; Tel.: (+34)-93-403-91-38
}

Received: 9 September 2019; Accepted: 24 September 2019; Published: 27 September 2019

\begin{abstract}
The study of the reactivity of three 2-phenyl-3H-indole ligands of general formulae $\mathrm{C}_{8} \mathrm{H}_{3} \mathrm{~N}-2-\left(\mathrm{C}_{6} \mathrm{H}_{4}-4-\mathrm{R}^{1}\right)-3-\mathrm{NOMe}-5-\mathrm{R}^{2}(\mathbf{1})$ [with $\mathrm{R}^{1}=\mathrm{H}, \mathrm{R}^{2}=\mathrm{OMe}(\mathbf{a}) ; \mathrm{R}^{1}=\mathrm{R}^{2}=\mathrm{H}(\mathbf{b})$ or $\mathrm{R}^{1}=\mathrm{Cl}$, $\left.\mathrm{R}^{2}=\mathrm{H}(\mathrm{c})\right]$ with $\left[\mathrm{Pd}\left(\eta^{3}-1-\mathrm{R}^{3} \mathrm{C}_{3} \mathrm{H}_{4}\right)(\mu-\mathrm{Cl})\right]_{2}\left(\mathrm{R}^{3}=\mathrm{H}\right.$ or $\left.\mathrm{Ph}\right)$ has allowed us to isolate two sets of new $\mathrm{Pd}(\mathrm{II})$-allyl complexes of general formulae $\left[\mathrm{Pd}\left(\eta^{3}-1-\mathrm{R}^{3} \mathrm{C}_{3} \mathrm{H}_{4}\right)(\mathbf{1}) \mathrm{Cl}\right]\left\{\mathrm{R}^{3}=\mathrm{H}(\mathbf{2})\right.$ or $\left.\mathrm{Ph}(\mathbf{3})\right\}$. Compounds 2a-2c and 3a-3c were characterized by elemental analyses, mass spectrometry and IR spectroscopy. The crystal structures of $\mathbf{2} \mathbf{a}, \mathbf{3} \mathbf{a}$ and $\mathbf{3} \mathbf{b}$ were also determined by $\mathrm{X}$-ray diffraction. ${ }^{1} \mathrm{H}$-NMR studies reveal the coexistence of two (for 2a-2c) or three (for 3a-3c) isomeric forms in $\mathrm{CD}_{2} \mathrm{Cl}_{2}$ solutions at $182 \mathrm{~K}$. Additional studies on the catalytic activity of mixtures containing $\left[\mathrm{Pd}\left(\eta^{3}-\mathrm{C}_{3} \mathrm{H}_{5}\right)(\mu-\mathrm{Cl})\right]_{2}$ and the parent ligand (1a-1c) in the allylic alkylation of (E)-3-phenyl-2-propenyl (cinnamyl) acetate with sodium diethyl 2-methylmalonate as well as the stoichiometric reaction between compounds 3a and $3 \mathrm{c}$ with the nucleophile reveal that in both cases the formation of the linear trans- derivative is strongly preferred over the branched product. Computational studies at a DFT level on compound 3a allowed us to compare the relative stability of their isomeric forms present in solution and to explain the regioselectivity of the catalytic and stoichiometric processes.
\end{abstract}

Keywords: Pd-allyl complexes; 2-phenyl-3H-indoles; homogeneous catalysis; computational studies; solution behavior

\section{Introduction}

Indole is one of the most important heterocycles for its presence in bioactive natural products, pharmaceuticals, and agrochemicals [1-9]. Indole derivatives are not only "privileged structures" in Medicinal Chemistry [1-4,6,10-12], due to their biological activity, but also valuable reagents for the design and synthesis of compounds with interesting properties and applications in a variety of fields [1-19]. The construction and functionalization of indoles have been studied since long ago; however, and as mentioned by Prof. M. Bandini some years ago "this field had a formidable boom across the new millennium when catalysis started revolutionizing the chemistry of indole" [7]. Interesting applications of novel indole derivatives as dyes [1-3,13], as components of Dye Sensitized Solar Cells (DSSC) [1-3,5] 
and as precursors in synthesis of organic compounds, including some natural products, have been reported $[1-3,15,17]$.

Indoles derivatives are also attracting a great deal of interest in coordination and organometallic chemistry because the binding of a transition metal atom to the indole nitrogen may introduce significant variations on the chemical, physical, photo-optical properties and catalytic or biological activities of this type of heterocycles [18]. However, M(II) complexes with 2-substituted-3H-indoles as ligands are not common. Mono-, di-, and even polymeric $\mathrm{Pd}(\mathrm{II}), \mathrm{Zn}(\mathrm{II}), \mathrm{Cd}(\mathrm{II}), \mathrm{Co}(\mathrm{II})$, complexes derived from 2-diformylmethylene-3,3-dimethylindole have been reported by Prof. Kaledi's group [19,20]. Some years ago, we focused our interest on 3-methoxyimino-2-phenyl-3H-indoles and the results obtained so far revealed not only that they may act as an $\mathrm{N}$-donor group (Figure 1A) $[21,22]$ or as a bidentate $\left[\mathrm{C}\left(\mathrm{sp}^{2}\right.\right.$, phenyl),N] $]^{-}$ligand (Figure 1B,C) [21-23] but also, that the resulting complexes exhibit interesting properties and biological activities. For instance, compounds $\mathbf{A}$ and $\mathbf{B}$ are more potent cytotoxic agents than their parent free ligands and even than cisplatin in MCF-7 and MDA-MB231 breast cancer cell lines [21,23].

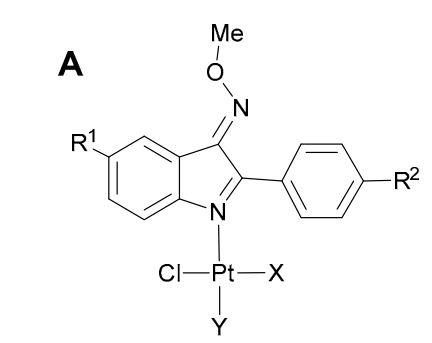

$\mathrm{R}^{1}=\mathrm{H}, \mathrm{R}^{2}=\mathrm{H}$ or $\mathrm{ClR}^{1}=\mathrm{OMe}, \mathrm{R}^{2}=\mathrm{H}$

$\mathrm{X}=\mathrm{Cl}, \mathrm{Y}=\mathrm{DMSO}$, trans-

$\mathrm{X}=\mathrm{DMSO}, \mathrm{Y}=\mathrm{Cl}$, cis-

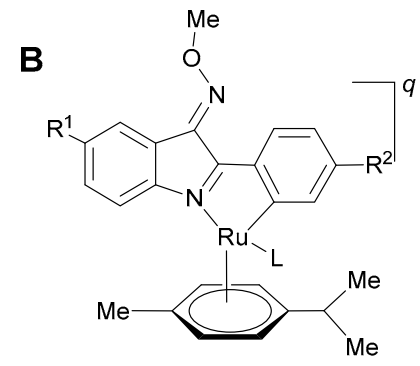

$\mathrm{R}^{1}=\mathrm{H}, \mathrm{R}^{2}=\mathrm{H}$ or $\mathrm{ClR}^{1}=\mathrm{OMe}, \mathrm{R}^{2}=\mathrm{H}$

$\mathrm{L}=\mathrm{Cl}, q=0$ or

$\mathrm{L}=\mathrm{CH}_{3} \mathrm{CN}, q=+1$

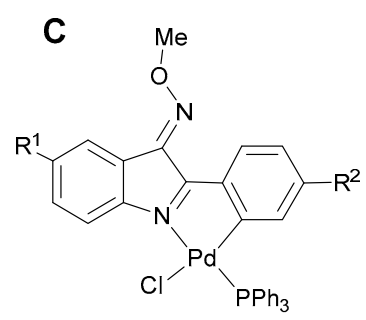

$\mathrm{R}^{1}=\mathrm{H}, \mathrm{R}^{2}=\mathrm{H}$ or $\mathrm{Cl}$

$\mathrm{R}^{1}=\mathrm{OMe}, \mathrm{R}^{2}=\mathrm{H}$

Figure 1. Three different types of compounds containing $\mathrm{Pt}(\mathrm{II})$ (A), $\mathrm{Ru}(\mathrm{II})$ (B) or $\mathrm{Pd}(\mathrm{II})$ (C) and 3-methoxyimino-2-susbtituted-3H-indoles as ligands [21-23].

Despite the increasing interest on: (a) novel transition metal complexes with indole ligands and especially the 2-sustituted-3H-indoles [18-20], (b) the role of $\mathrm{Pd}(\mathrm{II})$ in heterocyclic chemistry and in C-C bond formation (stoichiometric or catalytic) [24-27] and, (c) the relevance of "Pd(II)-allyl compounds" in homogeneous catalysis and their exciting solution behavior [25-35], $\mathrm{Pd}(\mathrm{II})$ compounds containing simultaneously "2-phenylindole" units and $\eta^{3}$-allyl ligands still remain unknown.

Here we present the first examples of $\mathrm{Pd}(\mathrm{II})$ complexes with 3-methoxyimino-2-phenyl-3H indoles (1a-1c) (shown in Scheme 1) and the allyl groups $\left(\eta^{3}-1-\mathrm{R}^{3} \mathrm{C}_{3} \mathrm{H}_{4}\right)\left(\mathrm{R}^{3}=\mathrm{H}\right.$ or 1-Ph) as ligands together with a study of their solution behavior and their potential utility in the allylic alkylation of (E)-3-phenyl-2-propenyl (cinnamyl) acetate with sodium diethyl 2-methylmalonate. Computational studies, based on DFT calculations, were undertaken in order to rationalize the stability and relative abundance of the co-existing isomeric forms in solution.

\section{Results and Discussion}

\subsection{Synthesis of the Pd(II) Compounds}

Compounds $\left[\mathrm{Pd}\left(\eta^{3}-1-\mathrm{R}^{3} \mathrm{C}_{3} \mathrm{H}_{4}\right)\left\{\mathrm{C}_{8} \mathrm{H}_{3} \mathrm{~N}-2-\left(\mathrm{C}_{6} \mathrm{H}_{4}-4-\mathrm{R}^{1}\right)-3 \mathrm{NOMe}-5-\mathrm{R}^{2}\right\} \mathrm{Cl}\right]\left[\mathrm{R}^{3}=\mathrm{H}(\mathbf{2 a - 2})\right.$ or $\mathrm{R}^{3}=\mathrm{Ph}$, $(3 \mathbf{a}-3 \mathbf{c})]$ were prepared by treatment of the corresponding $\left[\mathrm{Pd}\left(\eta^{3}-1-\mathrm{R}^{3} \mathrm{C}_{3} \mathrm{H}_{4}\right)(\mu-\mathrm{Cl})\right]_{2}\left(\mathrm{R}^{3}=\mathrm{H}\right.$ or $\mathrm{Ph}$ ) $[36,37]$ complexes with the proper 2-phenyl-3H-indole ligand (1a-1c) $\{$ in a molar ratio $\mathrm{Pd}(\mathrm{II}): \mathbf{1}=1: 1\}$ in $\mathrm{CH}_{2} \mathrm{Cl}_{2}$ at $298 \mathrm{~K}$ (Scheme 1). 


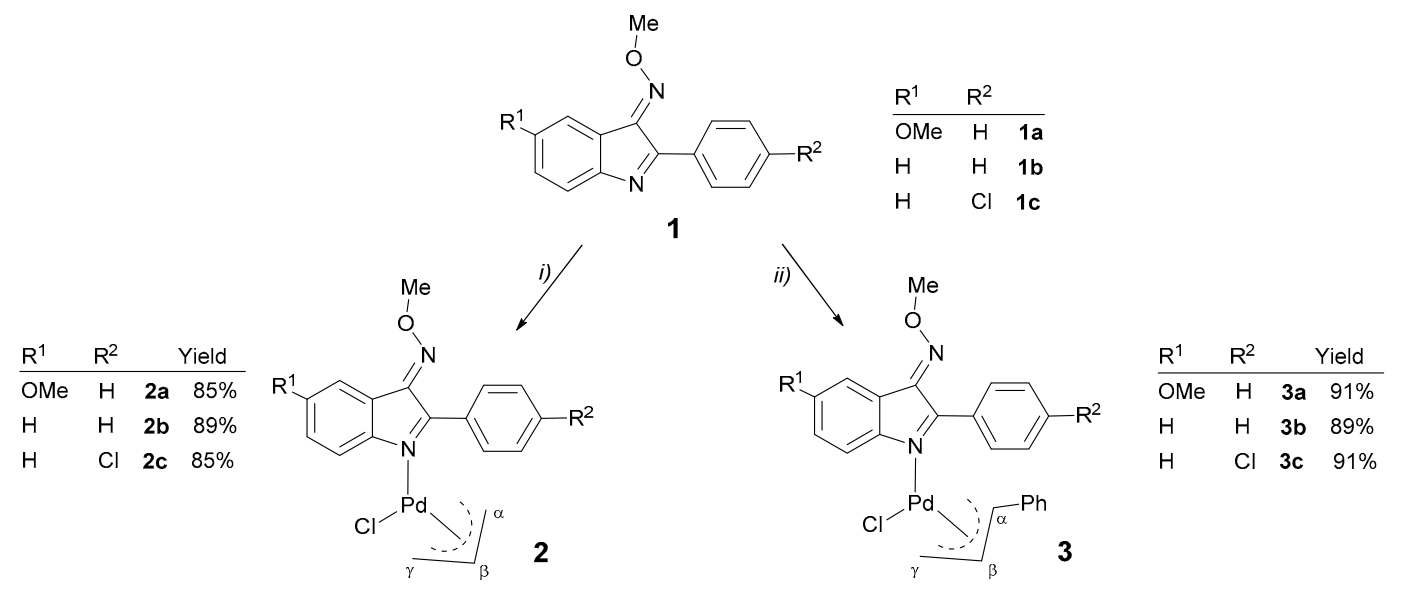

Scheme 1. Synthesis of compounds $2 \mathrm{a}-2 \mathrm{c}$ and $3 \mathrm{a}-3 \mathbf{c}$ and atom numbering pattern for the carbon atoms of the allylic backbone: (i) $\left[\mathrm{Pd}\left(\eta^{3}-\mathrm{C}_{3} \mathrm{H}_{5}\right)(\mu-\mathrm{Cl})\right]_{2}$, (ii) $\left[\mathrm{Pd}\left(\eta^{3}-1-\mathrm{PhC}_{3} \mathrm{H}_{4}\right)(\mu-\mathrm{Cl})\right]_{2}$ in $\mathrm{CH}_{2} \mathrm{Cl}_{2}$ at $298 \mathrm{~K}$ and using a molar ratio $\mathrm{Pd}(\mathrm{II})$ :ligand $=1: 1$.

The new products (2a-2c and 3a-3c) are stable solids at $298 \mathrm{~K}$, they exhibit high solubility in acetone, $\mathrm{CHCl}_{3}$ and $\mathrm{CH}_{2} \mathrm{Cl}_{2}$, but they are practically insoluble in $n$-hexane and diethylether. Characterization data are presented in the Supplementary Materials. Elemental analyses of $\mathbf{2 a - 2} \mathbf{c}$ and $3 \mathrm{a}-3 \mathbf{c}$ were consistent with the proposed formulae and their $\mathrm{ESI}^{+}$mass spectra showed a peak due to the corresponding $\{[\mathrm{M}]-\mathrm{Cl}\}^{+}$cation.

In the IR spectra of the new $\mathrm{Pd}(\mathrm{II})$ complexes the position of the band due to the stretching of the exocyclic $>\mathrm{C}=\mathrm{N}-$ group was practically identical to those of the parent free ligands and compounds A-C presented in Figure 1 [21-23] indicating that a) the $N_{\text {oxime }}$ atom was not bound to the $\mathrm{Pd}(\mathrm{II})$ atom and $\mathbf{b})$ the oxime unit adopted the anti-(E) form. X-ray diffraction studies of compounds $2 \mathbf{a}, 3 \mathbf{a}$ and $\mathbf{3 b}$ (see below), confirmed these findings. Keeping this in mind, complexes $\mathbf{2 a - 2} \mathbf{c}$ may exhibit two different isomeric forms (Figure 2) that differ in the relative arrangement between the central $C^{\beta}-\mathrm{H}^{\beta}$ bond of the allyl ligand and the phenyl ring (highlighted in deep red in Figure 2) of the bicyclic system.
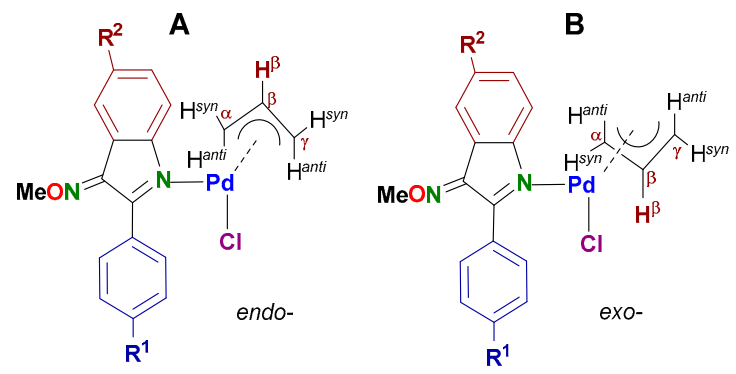

Figure 2. Schematic view of the two isomeric forms (A) (endo-) and (B) (exo-) of compounds $\left[\mathrm{Pd}\left(\eta^{3}-\mathrm{C}_{3} \mathrm{H}_{5}\right)\left\{\mathrm{C}_{8} \mathrm{H}_{3} \mathrm{~N}-2-\left(\mathrm{C}_{6} \mathrm{H}_{4}-4-\mathrm{R}^{1}\right)-3-\mathrm{NOMe}-5-\mathrm{R}^{2}\right\} \mathrm{Cl}\right]\left[\mathrm{R}^{1}=\mathrm{OMe}\right.$ and $\mathrm{R}^{2}=\mathrm{H}(\mathbf{2 a}), \mathrm{R}^{1}=\mathrm{R}^{2}=\mathrm{H}$ (2b) or $\left.\mathrm{R}^{1}=\mathrm{H}, \mathrm{R}^{2}=\mathrm{Cl}(\mathbf{2})\right]$.

For compounds $3 \mathbf{a}-\mathbf{3} \mathbf{c}$ the situation is markedly different due to presence of the non-symmetric 1- $\mathrm{PhC}_{3} \mathrm{H}_{4}$ allyl group. Assuming that the oxymino group adopts the anti-(E) form, eight different isomers (Figure $3 \mathbf{A}-\mathbf{H}$ ) could be formed in principle. They may differ in the relative disposition of the central $C^{\beta}-\mathrm{H}^{\beta}$ bond in respect to the phenyl ring of the bicyclic unit [endo- (in A-D) or exo- (in $\left.\left.\mathbf{E}-\mathbf{H}\right)\right]$. Moreover, the substituted carbon of the allyl ring $\left(\mathrm{C}^{\alpha}\right)$ could be located in a cis- (in A, B, E and F of Figure 3) or trans- (Figure 3, isomers $\mathbf{C}, \mathbf{D}, \mathbf{G}$ and $\mathbf{H}$ ) arrangement in respect to the indole nitrogen and, finally the phenyl ring of the $\left(\eta^{3}-1-\mathrm{PhC}_{3} \mathrm{H}_{4}\right)$ ligand could be in a syn- (in $\mathbf{A}, \mathbf{C}, \mathbf{E}$ and $\mathbf{G}$ ) or anti- (in $\mathbf{B}$, $\mathbf{D}, \mathbf{F}$ and $\mathbf{H})$ position in respect to the central hydrogen $\left(\mathrm{H}^{\beta}\right)$. 
A

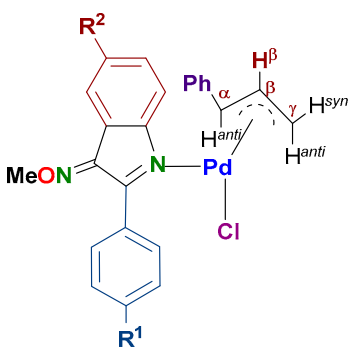

endo-, cis-N, syn-
B

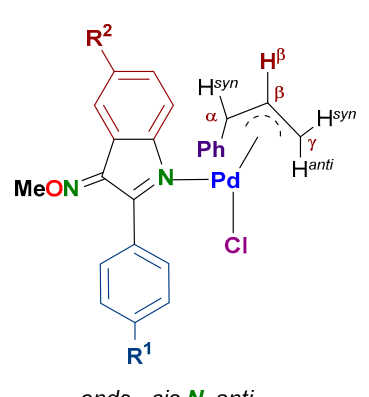

endo-, cis- $\mathrm{N}$, anti-
C

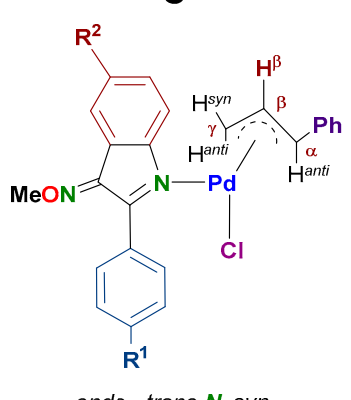

endo-, trans-N, syn-

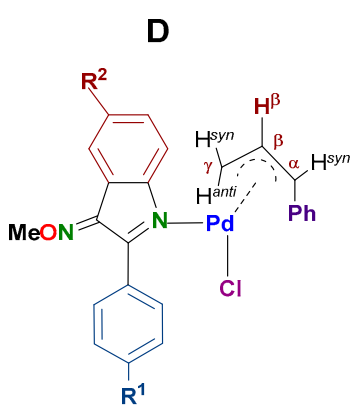

endo-, trans- $N$, anti-
E

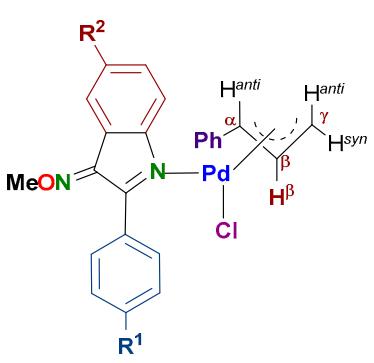

exo-, cis- $N$, syn-
$\mathbf{F}$

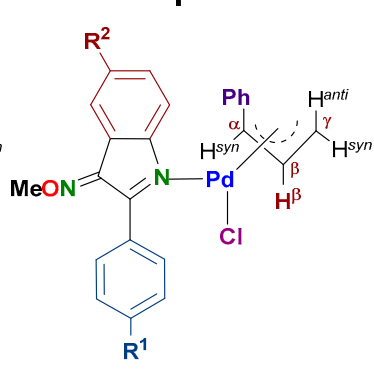

exo-, cis- $\mathbf{N}$, anti-

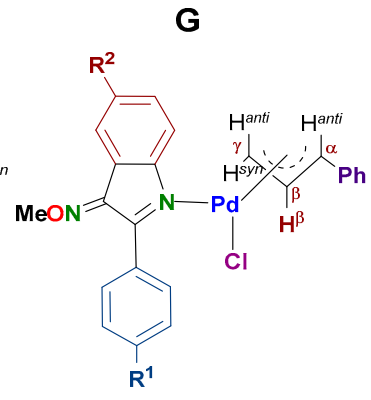

exo-, trans-N, syn-

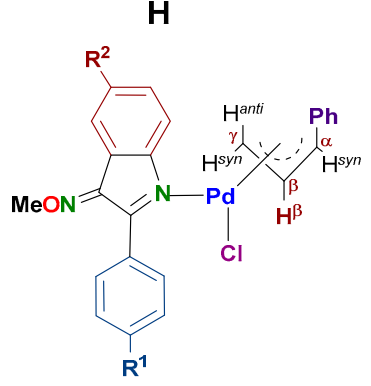

exo-, trans- $\mathrm{N}$, anti-

Figure 3. Schematic view of the different isomeric forms $(\mathbf{A}-\mathbf{H})$ of compounds $3 a-3 c .\left[R^{1}=H, R^{2}=O M e\right.$ (3a); $\mathrm{R}^{1}=\mathrm{R}^{2}=\mathrm{H}(\mathbf{3 b})$ or $\mathrm{R}^{1}=\mathrm{Cl}$ and $\mathrm{R}^{2}=\mathrm{H}(\mathbf{3} \mathbf{c})$ ], showing the relative arrangement of: a) the central $\mathrm{C}^{\beta}-\mathrm{H}^{\beta}$ bond of the allylic ligand in relation to the phenyl ring (depicted in deep red) of the indole bicycle (endo- or exo-); b) the substituted carbon of the 1-Ph- $\mathrm{C}_{3} \mathrm{H}_{4}$ unit and the indole nitrogen (cis- $\mathrm{N}$, or trans $-N$ ) and c) the phenyl ring of the allyl ligand in (syn- or anti-) in relation to the $\mathrm{H}^{\beta}$ atom.

\subsection{Description of the Crystal Structures of Compounds $\mathbf{2 a}, \mathbf{3 a}$ and $\mathbf{3 b}$}

Compounds $\mathbf{2 a}, \mathbf{3 a}$ and $\mathbf{3 b}$ were also characterized by X-ray diffraction. Crystal data and details of the refinement are presented in Table 1.

The crystal structure of $\mathbf{2 a}$ consists of molecules of $\left[\mathrm{Pd}\left(\eta^{3}-\mathrm{C}_{3} \mathrm{H}_{5}\right)\left\{\mathrm{C}_{8} \mathrm{H}_{3} \mathrm{~N}-2-\left(\mathrm{C}_{6} \mathrm{H}_{5}\right)-3-\mathrm{NOMe}-5-\right.\right.$ $(\mathrm{OMe})\} \mathrm{Cl}]$ (Figure 4) in which the $\mathrm{Pd}(\mathrm{II})$ atom $[\mathrm{Pd}(1)]$ is in a slightly distorted square-planar environment and it is bound to the heterocyclic nitrogen of the indole [N(1)], thus confirming the results obtained by IR studies. A chlorido ligand $[\mathrm{Cl}(1)]$ and the $\mathrm{C}_{3} \mathrm{H}_{5}$ moiety (in a $\eta^{3}$-fashion) fullfil the coordination sphere of the Pd(II). The differences detected in the Pd1-C17 [2.189(6) $\mathrm{A}$ ] and Pd-C19 [2.072(6) $\mathrm{A}]$ bond lengths can be ascribed to the influence of the ligand in a trans- arrangement ( $\mathrm{Cl} 1$ and $\mathrm{N} 1$, respectively). The $\mathrm{Pd}-\mathrm{N} / \mathrm{C} / \mathrm{Cl}$ bond lengths are similar to those reported for related $\left[\mathrm{Pd}\left(\eta^{3}-\mathrm{C}_{3} \mathrm{H}_{5}\right)(\mathrm{N}\right.$-heterocyclic ligand)Cl] complexes [35-41].

The indole unit is planar and nearly orthogonal to the coordination plane of the $\operatorname{Pd}(\mathrm{II})$ and the phenyl ring on position 2 forms an angle of ca. $35.0^{\circ}$ with the fused heterocycle. This arrangement of rings allows intramolecular hydrogen contacts between the heteroatoms of the "=NOMe" unit and the hydrogen atoms $\mathrm{H} 10$ and $\mathrm{H} 5$ [distances $\mathrm{N} 2 \cdots \mathrm{H} 10=2.578 \AA$ and $\mathrm{O} 2 \cdots \mathrm{H} 5=2.521 \AA$ ] . These short contacts, which reduce the flexibility of the pendant arm, were also observed in the crystal structures of the cyclometallated compounds containing $\mathrm{Pd}(\mathrm{II})$ or $\mathrm{Ru}(\mathrm{II})$ as well as in the trans- and cis- isomers of the $\mathrm{Pt}(\mathrm{II})$ complexes $(\mathrm{A}-\mathrm{C})$ shown in Figure 2 and appear to be characteristic of this family of ligands [21-23]. 
Table 1. Crystal data and details of the refinement of the crystal structures of compounds $\left[\mathrm{Pd}\left(\eta^{3}-1-\mathrm{R}^{3} \mathrm{C}_{3} \mathrm{H}_{4}\right)\left\{\mathrm{C}_{8} \mathrm{H}_{3} \mathrm{~N}-2-\left(\mathrm{C}_{6} \mathrm{H}_{4}-4-\mathrm{R}^{1}\right)-3-\mathrm{NOMe}-5-\mathrm{R}^{2}\right\} \mathrm{Cl}\right]$ with $\mathrm{R}^{3}=\mathrm{H}, \mathrm{R}^{2}=\mathrm{OMe}(\mathbf{2 a}) ; \mathrm{R}^{3}=\mathrm{Ph}$, $\mathrm{R}^{2}=\mathrm{OMe}$ and $\mathrm{R}^{1}=\mathrm{H}(\mathbf{3} \mathbf{a})$ and $\mathrm{R}^{2}=\mathrm{R}^{1}=\mathrm{H}(\mathbf{3 b})$.

\begin{tabular}{|c|c|c|c|}
\hline & $2 a$ & $3 \mathbf{a}$ & $3 b$ \\
\hline $\begin{array}{l}\text { Empirical formula } \\
\text { Formula weight }\end{array}$ & $\begin{array}{c}\mathrm{C}_{19} \mathrm{H}_{19} \mathrm{ClN}_{2} \mathrm{O}_{2} \mathrm{Pd} \\
449.21\end{array}$ & $\begin{array}{c}\mathrm{C}_{25} \mathrm{H}_{23} \mathrm{ClN}_{2} \mathrm{O}_{2} \mathrm{Pd} \\
525.30\end{array}$ & $\begin{array}{c}\mathrm{C}_{24} \mathrm{H}_{21} \mathrm{ClN}_{2} \mathrm{OPd} \\
495.28\end{array}$ \\
\hline Crystal sizes $/ \mathrm{mm} \times \mathrm{mm} \times \mathrm{mm}$ & $0.20 \times 0.10 \times 0.10$ & $0.20 \times 0.10 \times 0.10$ & $0.20 \times 0.10 \times 0.12$ \\
\hline Crystal system & Monoclinic & Monoclinic & Triclinic \\
\hline Space group & $\mathrm{C} 2 / \mathrm{c}$ & $\mathrm{P} 2_{1} / \mathrm{c}$ & P-1 \\
\hline$a / \AA$ & $18.953(10)$ & $14.461(4)$ & $9.813(3)$ \\
\hline$b / \AA$ & $7.137(3)$ & $15.481(4)$ & $14.180(4)$ \\
\hline$c / \AA$ & $28.722(8)$ & $10.096(4)$ & $16.556(3)$ \\
\hline$\alpha /$ deg. & 90.0 & 90.0 & $98.97(2)$ \\
\hline$\beta /$ deg. & 108.87(3) & $97.08(2)$ & 103.94(2) \\
\hline$\gamma /$ deg. & 90.0 & 90.0 & $98.88(2)$ \\
\hline$T / \mathrm{K}$ & $293(2)$ & $293(2)$ & $293(2)$ \\
\hline$\lambda / \AA ̊$ & 0.71073 & 0.71073 & 0.71073 \\
\hline$V / \AA^{3}$ & $3676(3)$ & $2243.0(12)$ & $2163.8(10)$ \\
\hline Z & 8 & 4 & 4 \\
\hline$D_{\text {calc }} / \mathrm{mg} \times \mathrm{m}^{3}$ & 1.623 & 1.556 & 1.520 \\
\hline$F(000)$ & 1808 & 1064 & 1000 \\
\hline$\mu / \mathrm{mm}^{-1}$ & 1.169 & 0.971 & 0.998 \\
\hline$\Theta$ range for data collection/deg. & from 2.271 to 32.345 & from 2.677 to 30.875 & from 1.761 to 30.361 \\
\hline N. of collected reflections & 3861 & 19380 & 18112 \\
\hline N. of unique reflections, $\left[R_{\text {int }}\right]$ & $3866[0.0543]$ & $5572[0.0275]$ & 9882 [0.0207] \\
\hline N. of parameters/N. of restrains & $214 / 6$ & $283 / 0$ & $524 / 0$ \\
\hline R indices, $[I>2 \sigma(\mathrm{I})]$ & $\begin{array}{r}\mathrm{R}_{1}=0.0534 \\
\mathrm{wR}_{2}=0.1652\end{array}$ & $\begin{array}{r}\mathrm{R}_{1}=0.0428 \\
\mathrm{w} \mathrm{R}_{2}=0.1013\end{array}$ & $\begin{array}{r}\mathrm{R}_{1}=0.0424 \\
\mathrm{wR}_{2}=0.1049\end{array}$ \\
\hline $\mathrm{R}$ indices (all data) & $\begin{array}{r}\mathrm{R}_{1}=0.0608 \\
\mathrm{wR}_{2}=0.1719\end{array}$ & $\begin{array}{c}\mathrm{R}_{1}=0.0446 \\
\mathrm{wR}_{2}=0.1030\end{array}$ & $\begin{array}{r}\mathrm{R}_{1}=0.0462 \\
\mathrm{wR}_{2}=0.1097\end{array}$ \\
\hline
\end{tabular}

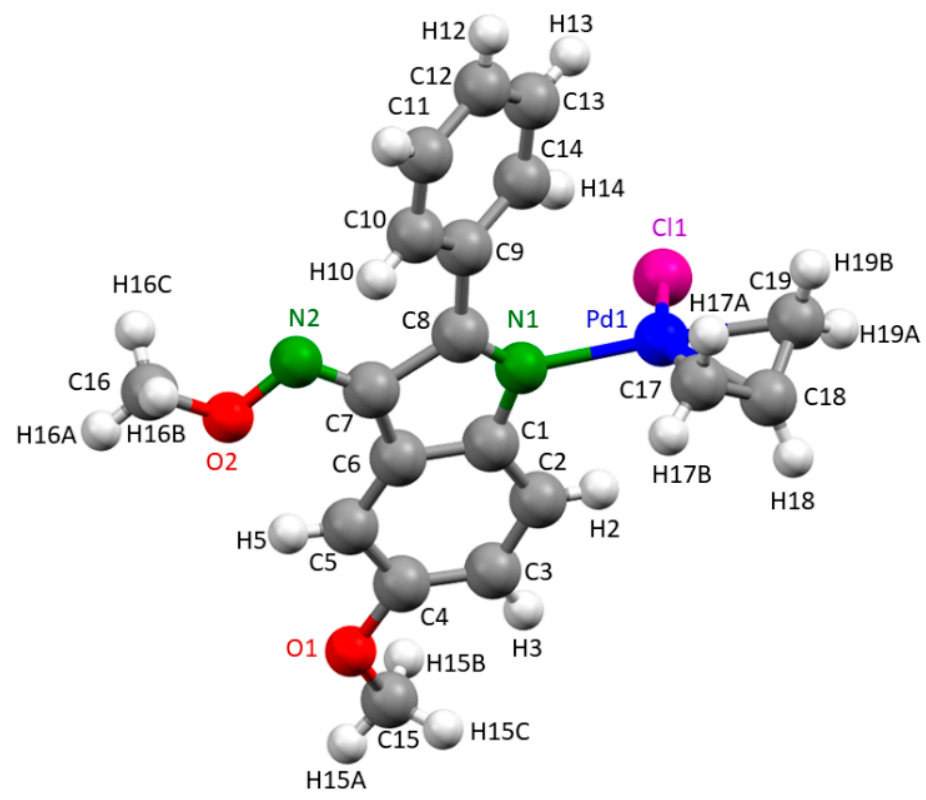

Figure 4. Molecular structure of $\left[\mathrm{Pd}\left(\eta^{3}-\mathrm{C}_{3} \mathrm{H}_{5}\right)\left\{\mathrm{C}_{8} \mathrm{H}_{3} \mathrm{~N}-2-\left(\mathrm{C}_{6} \mathrm{H}_{5}\right)-3-\mathrm{NOMe}-5-(\mathrm{OMe})\right\} \mathrm{Cl}\right]$ (2a). Selected bond lengths (in $\AA$ ) and angles (in deg.): Pd1-Cl1, 2.4815(11); Pd1-N1, 2.124(4); Pd1-C17, 2.189(6); Pd1-C18, 2.127(9); Pd1-C19, 2.072(6); C18-C17, 1.379(7); C19-C18, 1.375(7); Cl1-Pd1-N1; 94.23(10); C17-Pd1-N1, 101.43(19); C19-Pd1-Cl1, 99.15(19); C19-Pd1-C17, 65.2(2).

The central carbon atom of the allyl group C18 [Figure S1, (a)] is located out of the coordination plane of the palladium and on the same side as the $\mathrm{C} 1$ atom of the indole unit (endo-), therefore crystals of 2 a contain the endo- isomer (Figure 2, type A). The plane defined by three carbon atoms of the allyl 
group forms angles of $51.16^{\circ}$ and $38.79^{\circ}$ with those of the bicyclic system indole and the phenyl ring (C9-C14) attached to it, respectively.

In the crystal the molecules are connected by $\mathrm{C}-\mathrm{H} \cdots \mathrm{O}$ interactions involving the $\mathrm{C} 17-\mathrm{H} 17 \mathrm{~B}$ atoms of the allyl group of a molecule sited at $(x, y, z)$ and the oxygen $\mathrm{O} 2$ of a proximal unit at $(1-x, 1-y, z)$

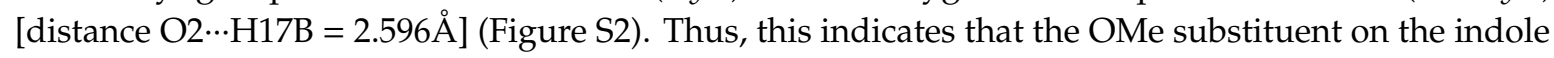
unit plays a crucial role in the molecular assembly in the solid state.

The X-ray crystal structure of 3a confirms the presence of $\left[\mathrm{Pd}\left(\eta^{3}-1-\mathrm{PhC}_{3} \mathrm{H}_{4}\right)\left\{\mathrm{C}_{8} \mathrm{H}_{3} \mathrm{~N}-2-\left(\mathrm{C}_{6} \mathrm{H}_{5}\right)-3-\right.\right.$ NOMe-5-(OMe) $\} \mathrm{Cl}$ ] molecules (Figure 5), in which the indole ligand binds to the $\mathrm{Pd}(\mathrm{II})$ through the heterocyclic nitrogen, N1. The orientation of the heterocycle as well as bond lengths and bond angles are similar to those of 2a. The phenyl ring forms angles of $45.50^{\circ}$ and $43.85^{\circ}$ with the indole and the oxymino group, respectively, thus allowing weak intramolecular $\mathrm{C} 14-\mathrm{H} 14 \cdots \mathrm{N} 2$ and $\mathrm{C} 5-\mathrm{H} 5 \cdots \mathrm{O} 2$ contacts [distances $\mathrm{N} 2 \cdots \mathrm{H} 14$ and $\mathrm{O} 2 \cdots \mathrm{H} 5$ being $2.610 \AA$ and $2.502 \AA$, respectively). The $\mathrm{Cl} 1$ ligand and the $\left(\eta^{3}-1-\mathrm{PhC}_{3} \mathrm{H}_{4}\right)$ allyl occupy the remaining coordination sites of the $\mathrm{Pd}(\mathrm{II})$.

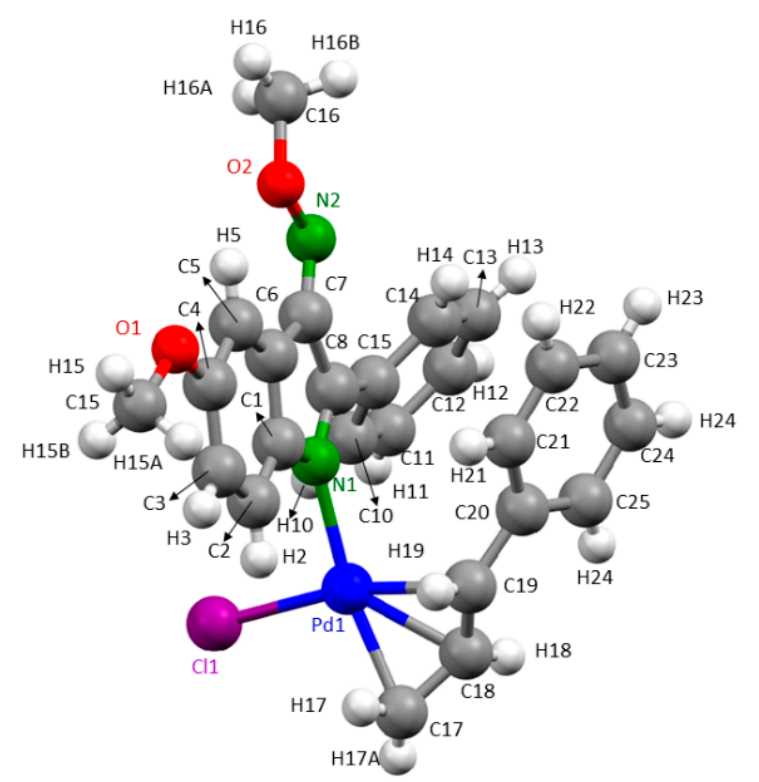

Figure 5. Molecular structure of $\left[\mathrm{Pd}\left(\eta^{3}-1-\mathrm{PhC}_{3} \mathrm{H}_{4}\right)\left\{\mathrm{C}_{8} \mathrm{H}_{3} \mathrm{~N}-2-\left(\mathrm{C}_{6} \mathrm{H}_{5}\right)-3 \mathrm{NOMe}-5(\mathrm{OMe})\right\} \mathrm{Cl}\right]$ (3a). Selected bond lengths (in $\AA$ ) and angles (in deg.): Pd1-Cl1, 2.3734(11); Pd1-N1, 2.115(2); Pd1-C17, 2.118(3); Pd1-C18, 2.118(3); Pd1-C19, 2.159(3); C18-C17, 1.384(5); C19-C18, 1.402(5); C11-Pd1-N1, 95.41(7); C19-Pd1-N1, 95.78(12); C17-Pd1-C11, 99.77(15); C19-Pd1-C17, 68.17(15).

In contrast with the results obtained for its analogue $\mathbf{2 a}$, the central C18 atom of the allyl ring of $\mathbf{3 a}$ and the atom $\mathrm{C} 1$ of the indole are located in opposite sides of the coordination plane of the $\mathrm{Pd}$ (II) atom (exo-). Besides this, the substituted carbon atom of the allyl ring (C19) is in a cis- arrangement in relation to the $\mathrm{Pd} 1-\mathrm{N} 1$ bond and the phenyl ring of the 1- $\mathrm{PhC}_{3} \mathrm{H}_{4}$ ligand occupies the syn- position [Figure $\mathrm{S} 1$, (b)]. All these findings confirm that the molecules present in the crystals of 3a correspond to the exo-, cis- $N$, syn-isomer (E in Figure 2). This distribution of rings and substituents allows intramolecular $\mathrm{C}-\mathrm{H} \cdots \pi$ interactions between: (a) the $\mathrm{H} 14$ atom and the phenyl ring of the allyl group, and (b) the $\mathrm{H} 21$ atom of the pentagonal cycle of the $3 \mathrm{H}$-indole [distances H14 $\cdots$ centroid of the $(\mathrm{C} 20-\mathrm{C} 25)$ ring $=3.477 \AA$

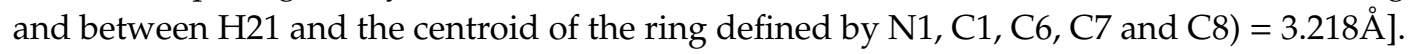

The assembly of the molecules in the crystals of $\mathbf{3 a}$ is markedly different from that of $\mathbf{2 a}$. In $\mathbf{3 a}$ two proximal molecules at $(x, y, z)$ and $(1-x, 1-y,-z)$ are connected by two C18-H18 $\cdots$ Cl1 short contacts (distance: $2.982 \AA$ ) forming dimers (Figure S3) that are assembled by $\mathrm{C}-\mathrm{H} \cdots \pi$ interactions.

Despite the formal similarity between compounds $\mathbf{3 a}$ and $\mathbf{3 b}$, the crystal structure of $\mathbf{3 b}$ is more complex than that of $\mathbf{3 a}$ due to the presence of two independent molecules of $\left.\left[\mathrm{Pd}\left(\eta^{3}-1 \mathrm{PhC}_{3} \mathrm{H}_{4}\right)\left\{\mathrm{C}_{8} \mathrm{H}_{3} \mathrm{~N}-2-\left(\mathrm{C}_{6} \mathrm{H}_{5}\right)-3-\mathrm{NOMe}\right)\right\} \mathrm{Cl}\right]$ (hereinafter referred to as $\mathbf{I}$ and $\mathbf{I I}$ ) that are shown in 
Figure 6. In both molecules the $\mathrm{Pd}(\mathrm{II})$ atoms are bound to a chlorido $\{\mathrm{Cl1A}$ or $\mathrm{Cl1B}\}$, the substituted allylic ligand in $\eta^{3}$ - fashion and the nitrogen of the indole ligand (N1A and N1B in I and II, respectively).
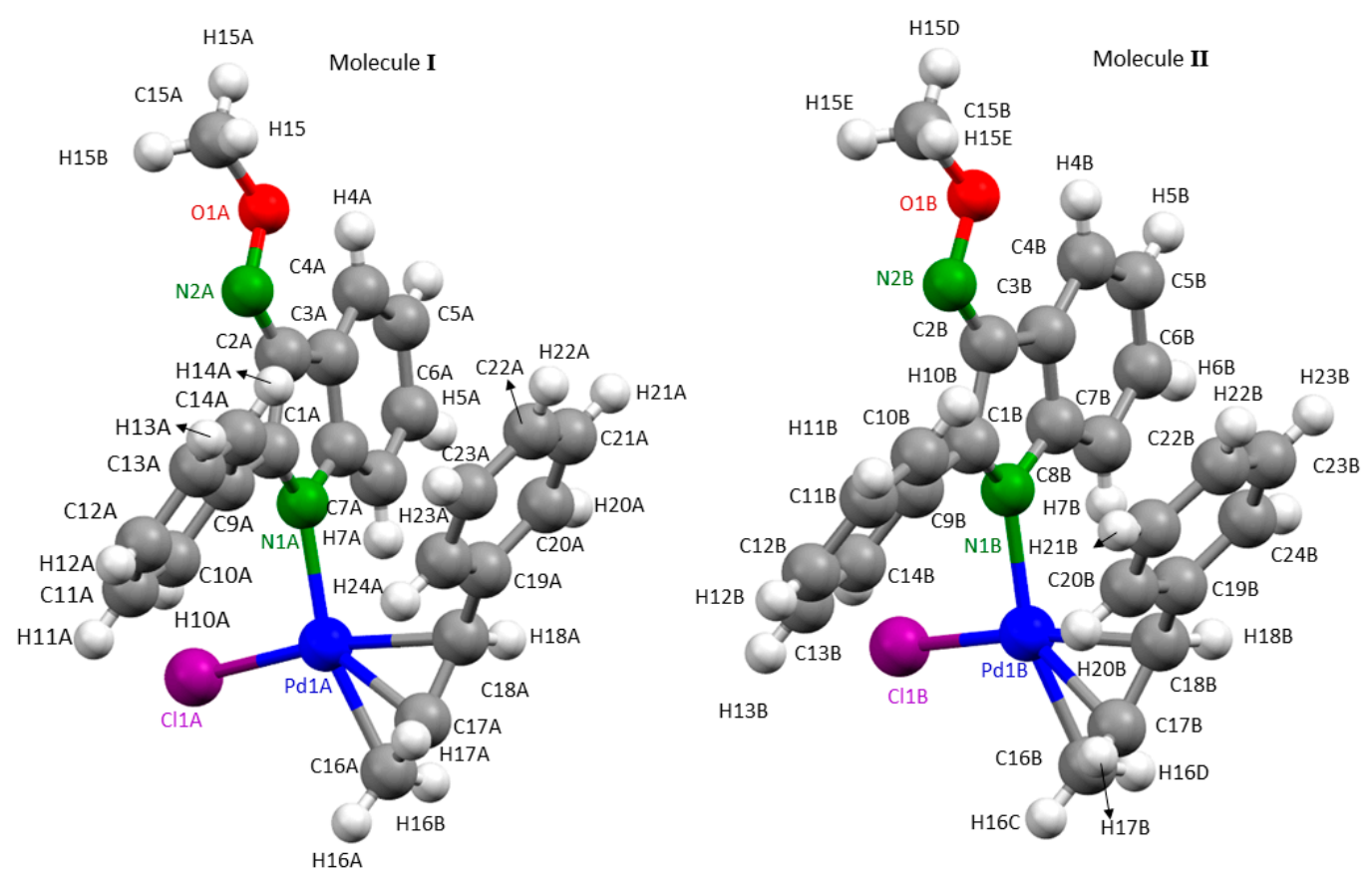

Figure 6. Molecular structure of the two different molecules (I and II) of [Pd( $\eta^{3}-1-\mathrm{PhC}_{3} \mathrm{H}_{4}$ ) $\left.\left.\left\{\mathrm{C}_{8} \mathrm{H}_{3} \mathrm{~N}-2-\left(\mathrm{C}_{6} \mathrm{H}_{5}\right)-3-\mathrm{NOMe}\right)\right\} \mathrm{Cl}\right]$ present in the crystal structure of $3 \mathbf{b}$. Selected bond lengths (in $\AA$ ) for molecule I: Pd1A- Cl1A, 2.3712(8); Pd1A-N1A, 2.129(2); Pd1A-C16A, 2.113(3); Pd1A-C17A, 2.115(3); Pd1A-C18A, 2.161(3); C16A-C17A,1.410(6); C17A-C18A, 1.388(5); N1A- C1A, 1.309(3); O1A-N2A, 1.381(4); O1A-C15A, 1.434(4) and, for molecule II: Pd1B- Cl1B, 2.3741(13); Pd1B-N1B, 2.120(2); Pd1B-C16B, 2.108(3); Pd1A-C17B, 2.116(4); Pd1B-C18B, 2.141(4); C16B-C17B, 1.393(6); C17B-C18B, 1.416(5); N1B-C1B, 1.299(3); O1B-N2B, 1.375(4); O1B-C15B, 1.430(4). Selected bond angles (in deg.) for molecule I: N1A-Pd1A-Cl1A, 95.70(7); N1A-Pd1A-C18A, 94.75(11); Cl1A-Pd1A-C16A, 99.87(11); C16A-Pd1A-C18A, 68.75(14); C2A-N2A-O1A, 110.3(3); N2A-O1A-C15A, 109.5(3); for molecule II: N1B-Pd1A-Cl1A, 96.00(7); N1A-Pd1A-C18A, 95.52(12); C11A-Pd1A-C16A, 99.83(14); C16A-Pd1A-C18A, 69.23(16); C2B-N2B-O1B, 110.7(3) and N2A-O1A-C15A, 109.7(3).

Bond lengths and angles around the $\mathrm{Pd}(\mathrm{II})$ atoms are similar to those found for compound $3 \mathrm{a}$ and related complexes containing [ $\mathrm{Pd}\left(\eta^{3}-1-\mathrm{PhC}_{3} \mathrm{H}_{4}\right)(\mathrm{N}$-donor ligand) $\mathrm{Cl}]$ [32,38-41]. In molecules I and II the phenyl ring of the indole unit and the central $\mathrm{C}-\mathrm{H}$ bond of the allyl ligand are located on opposite sides of the coordination plane of the $\mathrm{Pd}(\mathrm{II})$ atoms (exo-). Moreover, the substituted carbon of the allyl ligand (C18A in I and C18B in II) and the indole nitrogen are in a cis- arrangement [bond angles N1APd1- C18A $=94.75(1)^{\circ}$ and N1B-Pd1B- C18B $\left.=95.52(12)^{\circ}\right]$ and, finally the phenyl ring is in the synposition in relation to the central hydrogen atom (H17A in I and H17B in II)] of the allyl ring (syn-) [Figure S1]. All these findings indicate that both molecules correspond to the exo-, cis- $N$, syn- isomer, exactly the same type of isomer ( $\mathbf{E}$ in Figure 3 ), as that found in the crystals of $\mathbf{3 a}$.

Bond lengths and angles of molecules I and II are similar, and the most evident difference lies in the coplanarity between the oxymino group and the indole unit, which is higher in molecule II than in molecule I. The orientation of the phenyl defined by the set of atoms (C10A-C14A in I or C10B-C14B in II) versus the bicyclic system is a bit different (ca. $2.6^{\circ}$ ). Despite of these differences, again the relative arrangement of the NOMe unit allows short intramolecular contacts (Figure S1c) similar to those found in 2a, 3a and also in other $\mathrm{Pt}, \mathrm{Ru}$, or Pd complexes prepared previously in our group [21-23].

In the crystals, (Figure S4) two molecules of the same kind are assembled by $\mathrm{CH}$ … Cl intermolecular short contacts. Further, C-H $\cdots \pi$ interactions involving the H11A of a type I molecule with the C19A-C24A 
ring of a close unit, and the allylic hydrogen H18A and the phenyl ring on site-2 of a proximal type II unit, generate the molecular architecture.

\subsection{Solution Studies}

\subsubsection{Allylic Alkylation Reactions}

As mentioned above, the increasing interest on indole-chemistry and also on Pd(II)-allyl complexes is mainly due to their potential utility in synthesis and catalysis $[1-5,25-28,34,35,42-44]$. However, as far as we know, the use of 2-phenyl-3H-indoles or their transition metal complexes in homogeneous catalysis still remains unexplored. Since: (a) palladium(II) catalytic allylic alkylation is one of the most widely studied processes due to the formation of $\mathrm{C}-\mathrm{C}$ and $\mathrm{C}$-heteroatom bonds that is relevant in synthesis, including the preparation of natural products [25-28,44] and, (b) there is a lack of studies on the use of indoles in $\mathrm{Pd}(\mathrm{II})$ catalyzed allylic alkylations, we also investigated the potential utility of compounds 1a-1c in the allylic alkylation of (E)-3-phenyl-2-propenyl (cinnamyl) acetate with sodium diethyl 2-methylmalonate (Scheme 2).

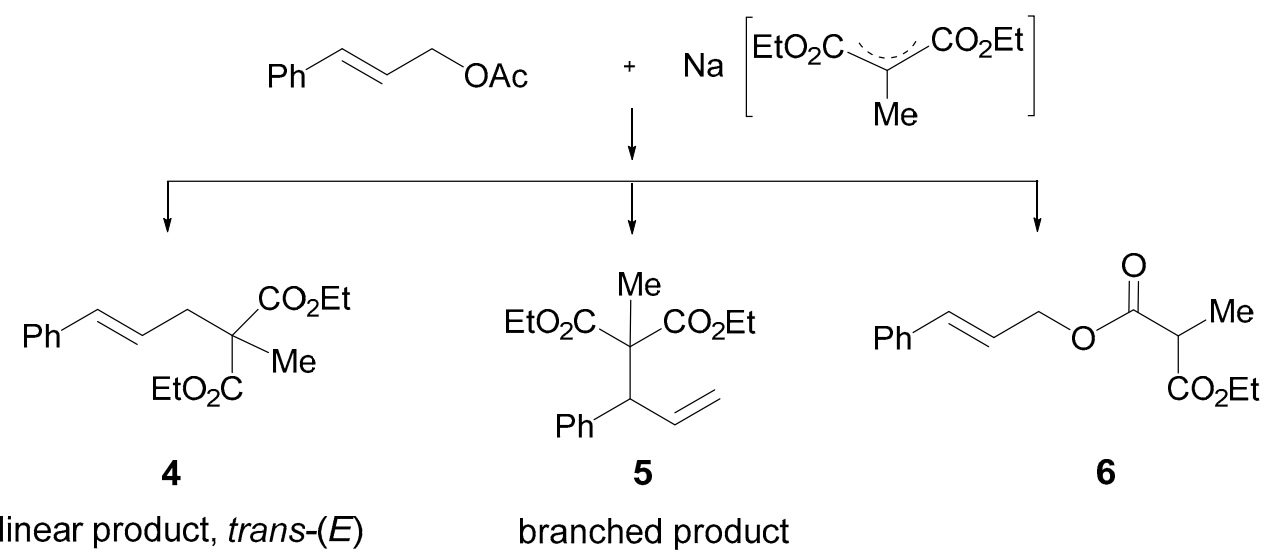

Scheme 2. Catalytic allylic alkylation of cinnamyl acetate with sodium diethyl 2-methylmalonate under study (see also footnote $a$ in Table 2).

In all the studied reactions the precursors were prepared in situ by treatment of $\left[\mathrm{Pd}\left(\eta^{3}-\mathrm{C}_{3} \mathrm{H}_{5}\right)(\mu-\mathrm{Cl})\right]_{2}$ and the corresponding ligand $(\mathbf{1 a}-\mathbf{1 c})$ and the catalytic processes were performed in THF under mild experimental conditions using different reaction periods $(t)$. Results, presented in Table 2, reveal that the indole ligands 1a-1c are active in the catalytic alkylation of cinnamyl acetate. For $t=24 \mathrm{~h}$ the process gave: the linear trans-(E) product (4), the branched derivative (5) and 1-cinnamyl-3-ethyl-2-methylmalonate (6). Under these experimental conditions the conversion varies from $87 \%$ (for $1 \mathrm{~b}$ ) to $91 \%$ (for $1 \mathrm{c}$ ), but the presence of compound 6 reduces the effectiveness of the catalytic systems $\mathbf{1 a}, \mathbf{1} \mathbf{b}$ or $\mathbf{1} \mathbf{c}$ and $\left[\mathrm{Pd}\left(\eta^{3}-\mathrm{C}_{3} \mathrm{H}_{5}\right)(\mu-\mathrm{Cl})\right]_{2}$. It should be noted that compound $\mathbf{6}$ is also formed when cinnamyl acetate is treated with the nucleophile in THF under identical experimental conditions, but in the absence of the catalyst [32,33].

Better results were obtained for longer reaction periods $[t=96 \mathrm{~h}$, (Table 2, entries $I V-V I)]$. Conversions increased and the relative abundance of the undesirable side product (6) decreased considerably. It should be noted that for $1 \mathrm{c}$ no evidence of the presence of $\mathbf{6}$ was detected. In these cases, the formation of the linear trans-(E) product (4) was strongly preferred over that of the branched isomer (5). The comparison of results obtained after $96 \mathrm{~h}$, also reveal that the regioselectivity of this process towards the linear product increases according to the sequence: $\mathbf{1 a}<\mathbf{1 b} \leq \mathbf{1 c}$. 
Table 2. Results of the catalytic allylic alkylation of cinnamyl acetate with sodium diethyl-2methylmalonate using a mixture of $\left[\mathrm{Pd}\left(\eta^{3}-\mathrm{C}_{3} \mathrm{H}_{5}\right)(\mu-\mathrm{Cl})\right]_{2}$ and the corresponding ligand. ${ }^{a}$.

\begin{tabular}{ccccc}
\hline Entry & $\mathbf{1}^{\text {Ligand }}$ & T (h) & Conversion $^{2} \mathbf{( \% )}$ & $\begin{array}{c}\text { Molar Ratio }^{3} \\
\text { 4:5:6 }\end{array}$ \\
\hline$I$ & $1 \mathrm{a}$ & 24 & 89 & $76: 6: 18$ \\
$I I$ & $1 \mathrm{~b}$ & 24 & 87 & $74: 7: 19$ \\
$I I I$ & $1 \mathrm{c}$ & 24 & 91 & $83: 7: 10$ \\
$I V$ & $1 \mathrm{a}$ & 96 & $>99$ & $88: 8: 4$ \\
$V$ & $1 \mathrm{~b}$ & 96 & $>99$ & $91: 6: 2$ \\
$V I$ & $1 \mathrm{c}$ & 96 & $>99$ & $92: 9: 0$ \\
\hline
\end{tabular}

${ }^{1}$ Experimental conditions: at room temperature, tetrahydrofuran (THF) solutions of the corresponding ligand (1a-1c) $\left(5.0 \times 10^{-3} \mathrm{mmol}\right.$ in $\left.1 \mathrm{~mL}\right),\left[\mathrm{Pd}\left(\eta^{3}-\mathrm{C}_{3} \mathrm{H}_{5}\right)(\mu-\mathrm{Cl})\right]_{2}\left(2.5 \times 10^{-3} \mathrm{mmol}\right.$ in $\left.1 \mathrm{~mL}\right)$ the allylic substrate $(0.5 \mathrm{mmol}$ in $1 \mathrm{~mL})$, and sodium diethyl 2-methylmalonate, $(1.0 \mathrm{mmol}$ in $2 \mathrm{~mL})$ were mixed in that precise order and stirred for 24 or $96 \mathrm{~h} .{ }^{2}$ Analyzed by gas chromatography. ${ }^{3}$ Product distribution: linear trans-(E) alkylation product (4), branched product (5) and 1-cinnamyl-3-ethyl-2-methylmalonate (6).

Scheme 3 shows two important steps [i) and ii)] of the mechanism accepted for palladium catalyzed allylic alkylation of cinnamyl acetate with soft nucleophiles (such as sodium diethyl 2-methylmalonate) [42-44] where $\mathrm{L}^{1}$ and $\mathrm{L}^{2}$ represent either two monodentate ligands (commonly a N- donor and a chlorido) or one bidentate ligand. It is well-known that the regio-, as well as the stereoselectivity, of the process are dependent on several factors that include the number and structures of the different isomeric forms of the intermediate species (IS) formed in step ii), their interconversion rates and the ease with which they undergo the nucleophilic attack in solution. [18,23,42-44].

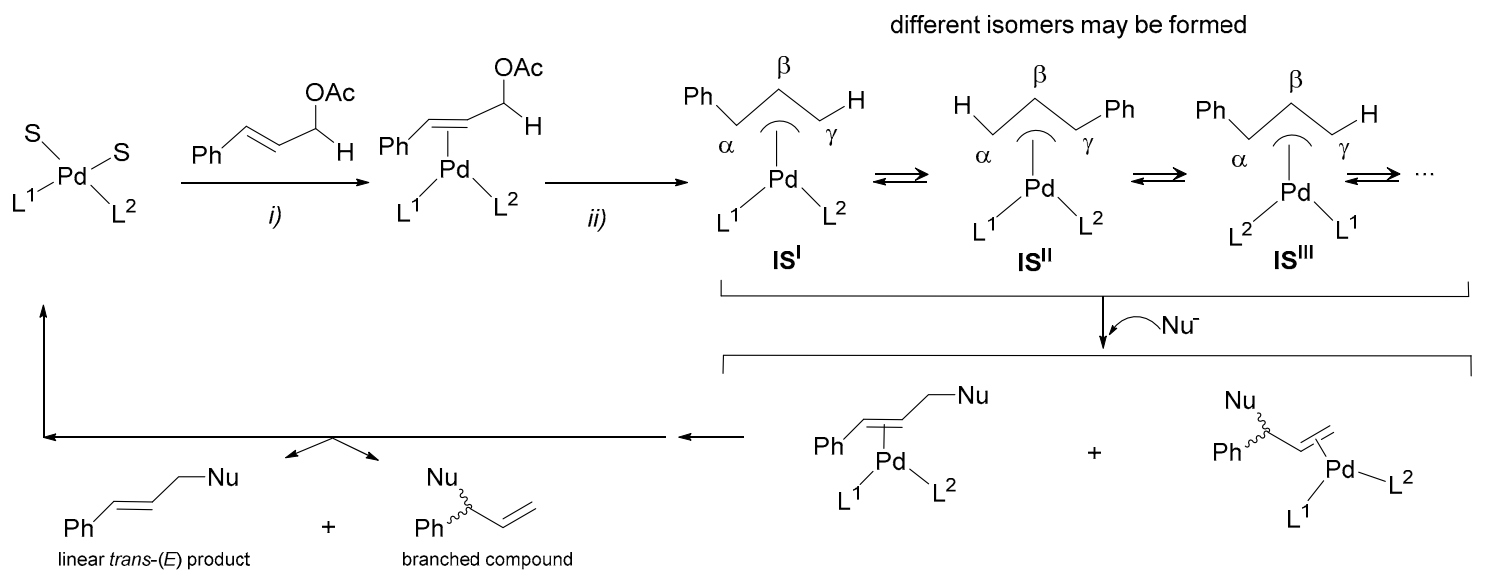

Scheme 3. Part of the mechanism for the palladium catalyzed allylic alkylation of (E)-3-phenyl-2-propenyl (cinnamyl) acetate using soft nucleophiles [ $\mathrm{L}^{1}$ and $\mathrm{L}^{2}$ are two monodentate ligands or a bidentate ligand, $\mathrm{S}$, the solvent, and $\mathrm{Nu}^{-}$the nucleophile). $\mathbf{I S}^{\mathrm{i}}$ represent the intermediate species formed and the superscript ${ }^{i}$ (i = I, II, III, etc.) refer to the different isomers that could co-exist in solution. (These $\mathbf{I S}^{\mathbf{i}}$ species may undergo the attack of the nucleophile $\left(\mathrm{Nu}^{-}\right)$on different sites and/or at different rates).

In compounds $\mathbf{3 a}-\mathbf{3} \mathbf{c}$ the environment of the $\mathrm{Pd}(\mathrm{II})$ atom is similar to that of the intermediate species IS with the ancillary ligands being a $\mathrm{Cl}^{-}$and the corresponding indole (1a-1c). In view of this and the results obtained from the catalytic studies we also investigated the direct reaction between the allyl compounds $3 \mathbf{a}$ and $\mathbf{3 c}$ separately with an excess of sodium diethyl 2-methylmalonate in THF at $298 \mathrm{~K}$ (stoichiometric reaction). These reactions were instantaneous and gave, after work-up, a mixture of the trans- $(E)$ isomer of the linear product (4) and the branched derivative (5) in molar ratios of 98.3:1.7 (for 3a) and 99.6:0.4 (for 3c). It should be noted that the presence of the side product cis-(Z) isomer of the linear product and compound 6 were not detected by NMR. Therefore, the preferential formation of the linear trans- $(E)$ product in the catalytic and stoichiometric reactions can be explained 
assuming that the attack of the nucleophile takes place at the terminal $\mathrm{C}^{\gamma}$ atom of the $\left(\eta^{3}-1-\mathrm{PhC}_{3} \mathrm{H}_{4}\right)$ ligand of one or more isomers of IS.

In order to get further information about the number of isomeric forms of 3a-3c present in solution and their characteristics, we also studied their solution behavior by NMR. For comparison purposes a parallel study with their analogues $\mathbf{2 a}-\mathbf{2} \mathbf{c}$ with the $\left(\eta^{3}-\mathrm{C}_{3} \mathrm{H}_{5}\right)$ ligand was also included.

\subsubsection{Study of the Solution Behaviour of the New Pd(II) Allyl Compounds}

${ }^{1} \mathrm{H}-\mathrm{NMR}$ spectra of $\mathbf{2 a - 2} \mathbf{c}$ in $\mathrm{CD}_{2} \mathrm{Cl}_{2}$ at $298 \mathrm{~K}$ showed broad signals (Figures S5-S7). This could be indicative of the co-existence of several isomeric species in solution. Since: a) the X-ray crystal structures of compounds $\mathbf{2} \mathbf{a}, \mathbf{3} \mathbf{a}$ and $\mathbf{3} \mathbf{b}$ confirmed that the $\mathrm{Pd}(\mathrm{II})$ atom was bound to the heterocyclic nitrogen of the indole ligand, we assumed that in all the isomers of compounds $\mathbf{2}$ the indole ligands behaved as $N_{\text {indole }}$ donor group and the anti- $(E)$ form adopted by the oxymino moiety was retained. VT-NMR studies in $\mathrm{CD}_{2} \mathrm{Cl}_{2}$ for 2a-2c, (Figures S5-S7) showed that upon cooling the signals detected in the ${ }^{1} \mathrm{H}$-NMR spectra became narrower and at $182 \mathrm{~K}$ two sets of superimposed groups of resonances of relative intensities 1.00:0.60 (for 2a); 1.00: 0.62 (for $\mathbf{2 b}$ ) and 1.00:0.65 (for 2c)] were clearly identified (Figures S8-S10). These findings suggest the co-existence of the two isomeric forms of compounds 2 [A (endo-) and $\mathbf{B}($ exo-) depicted in Figure 2] and that the energy required for their interconversion is small.

The ${ }^{1} \mathrm{H}-\mathrm{NMR}$ spectra of $\mathrm{CD}_{2} \mathrm{Cl}_{2}$ solutions of compounds $3 \mathrm{a}-3 \mathbf{c}$ at $298 \mathrm{~K}$ exhibited broad signals (for illustrative purposes that of 3a is shown in Figure S11), but upon cooling the resolution of the spectra improved considerably and at $182 \mathrm{~K}$ (Figures S11,S12) two sets of superimposed signals of relative intensities 1.00:0.64 were clearly identified, thus suggesting the presence of two isomeric species \{herein after referred to as $\mathbf{3} \mathbf{a}^{\mathbf{I}}$ (major) and $\mathbf{3} \mathbf{a}^{\mathrm{II}}$ (minor)\} in solution. However, a careful analysis of the signals observed indicated the presence of other minor species in low abundance $(<10 \%)$. The ${ }^{1} \mathrm{H}-\mathrm{NMR}$ spectra of compounds $3 \mathbf{b}$ and $3 \mathbf{c}$ at $182 \mathrm{~K}$, also revealed the presence of two major isomers in solution in molar ratios 1.00:0.74 and 1.00:0.62 for $\mathbf{3 b}$ and 3c, respectively. (Figures S13 and S14). It should be noted that additional set of signals with lower intensities suggested the presence of traces of another isomer of $\mathbf{3 b}$; while for $\mathbf{3} \mathbf{c}$, no evidences of the coexistence of other species in solution were detected by NMR at $182 \mathrm{~K}$.

For the two major isomers, detected in the $\mathrm{CD}_{2} \mathrm{Cl}_{2}$ solutions of $3 \mathrm{a}-3 \mathrm{c}$ at $182 \mathrm{~K}$, the values of the coupling constants ${ }^{3} \mathrm{~J}\left(\mathrm{H}^{\gamma}, \mathrm{H}^{\beta}\right)$ indicate that the phenyl ring is in the syn- position in relation to the $\mathrm{H}^{\beta}$ hydrogen, and the chemical shifts of the allylic $\mathrm{H}_{\text {anti }}{ }^{\alpha} \mathrm{H}_{s y n}{ }^{\alpha}$ and $\mathrm{H}^{\gamma}$ nuclei were similar to those found in related complexes holding the " $\left[\mathrm{Pd}\left(\eta^{3}-1-\mathrm{PhC}_{3} \mathrm{H}_{4}\right) \mathrm{Cl}\right]$ " and a neutral organic ligand bound to the $\mathrm{Pd}(\mathrm{II})$ through a Nsp${ }^{2}$ atom in a cis- arrangement to the substituted carbon of the allyl ligand [32,33] and the analysis of NOE peaks in the $\left[{ }^{1} \mathrm{H}^{-}{ }^{1} \mathrm{H}\right]$ NOESY spectrum (Figure S12) confirmed this hypothesis. On these bases, we assumed that the major isomers of $3 \mathbf{a}-3 \mathbf{c}$ present in $\mathrm{CD}_{2} \mathrm{Cl}_{2}$ solution at $182 \mathrm{~K}$ differ exclusively in the orientation of the allyl unit (endo- or exo-). The low abundance of the remaining minor species detected by NMR did not allow us to identify them unambiguously. Computational studies (described in the following section) allowed us to clarify this point.

\subsection{Computational Studies}

In a first attempt to rationalize the experimental results and in particular: (a) to explain the coexistence of several isomers of compounds $3 \mathbf{a}-\mathbf{3 c}$ and their relative stability in solution under the experimental conditions, (b) to rationalize the preferential formation of the linear trans- $(E)$ product in the Pd catalyzed allylic alkylation of cinnamyl acetate with sodium diethyl 2-methylmalonate versus the branched derivative and, (c) to try to clarify the origin of the formation of the branched product (5), we decided to undertake DFT calculations.

Since NMR studies revealed that compounds $3 \mathbf{a}-\mathbf{3} \mathbf{c}$ showed a similar solution behavior in $\mathrm{CD}_{2} \mathrm{Cl}_{2}$, the computational studies were carried out for $3 \mathbf{a}$ as a representative product of this series. Computational studies were performed assuming that in all the cases the oxymino unit retained the anti- $(E)$ form. Experimental IR and NMR data as well the X-ray diffraction studies presented in this 
work support this hypothesis. Therefore, only eigth isomers of compound $\mathbf{3 a}(\mathbf{A}-\mathbf{H}$, in Figure 3 with $\mathrm{R}^{1}=\mathrm{H}$ and $\mathrm{R}^{2}=\mathrm{OMe}$ ) were selected for this study.

Computational calculations carried out using the B3LYP hybrid functional $[45,46]$ and the LANL2DZ basis set [47] implemented in the Gaussian09 program. [48] In the first step, geometries of the eight isomers were optimized (Figure S15) and final atomic coordinates are presented in Tables S1-S8. Afterwards the total energy $\left(E_{T}\right)$ of the eight isomers was calculated in the gas phase and in $\mathrm{CH}_{2} \mathrm{Cl}_{2}$ solution. As shown in Table S9, in the gas phase minima $\left(E_{T}\right)$ values correspond to two isomers. One of them $\mathbf{E}($ exo-, cis- $N$, syn-) is that found the crystal structure of $\mathbf{3 a}$; while the other was isomer $\mathbf{A}$ (endo-, $c i s-N$, syn-). This suggests that that these isomers, that differ exclusively in the conformation of the allyl ligand, are clearly more stable than the remaining six.

Since VT-NMR studies described above were carried out in $\mathrm{CD}_{2} \mathrm{Cl}_{2}$, we also determined the $E_{T}$ values in dichloromethane by PCM calculations, [49] (Table S9). The obtained $E_{T}$ values and the calculated relative energies $\left[\Delta E_{T}=E_{T}\right.$ (for a given isomer) $-E_{T}$ (for isomer $\mathbf{E}$, that has the lowest $\mathrm{E}_{\mathrm{T}}$ )] increase according to the following sequence: $\mathbf{E}($ exo-, cis- $N$, syn- $) \approx \mathbf{A}\left(\right.$ endo-, cis- $N$, syn-),$\Delta E_{T}=0.01<$ $\mathbf{G}\left(\right.$ exo-, trans- $N$, syn-) $, \Delta E_{T}=1.22<\mathbf{C}($ endo-, trans- $N$, syn- $), \Delta E_{T}=1.82<<\mathbf{H}($ exo-, trans- $N$, anti- $), \Delta E_{T}$ $=3.47 \leq \mathbf{D}$ (endo-, trans- $N$, anti- $), \Delta E_{T}=3.58<\mathbf{F}($ exo- , cis- $N$, anti- $), \Delta E_{T}=3.67<<\mathbf{B}($ endo-, cis- $N$, anti- $)$, $\Delta E_{T}=4.36$.

Now the energies of isomers $\mathbf{A}$ (endo-, cis- $N$, syn-) and $\mathbf{E}$ (exo-, cis- $\mathrm{N}$, syn-) only differ in $0.01 \mathrm{kcal} / \mathrm{mol}$ and they may be considered as isoenergetics. On these basis, the energy required to change orientation of the central $C^{\beta}-\mathrm{H}^{\beta}$ bond of the allyl ligand in relation to the indole from exo-in $\mathbf{E}$ to endo- in $\mathbf{A}$ is expected to be small enough as to allow the co-existence of both isomers at room temperature we will return to this point later on. Isomers $\mathbf{C}$ (endo-, trans- $N$, syn-) and $\mathbf{G}$ (exo-, trans- $N$, syn-), that can visualized as derived from their analogues $\mathbf{A}$ and $\mathbf{E}$ by a cis- $N \rightarrow$ trans $-N$ isomerization process, are higher in energy than $\mathbf{A}$ and $\mathbf{E}$ but the differences are small $(1.21$ and $1.82 \mathrm{kcal} / \mathrm{mol}$, for $\mathbf{C}-\mathbf{A}$ and G-E, respectively).

It is interesting to point out that in isomers $\mathbf{H}$ (exo-, trans- $N$, anti-), $\mathbf{D}$ (endo-, trans- $N$, anti-), $\mathbf{F}$ (exo, cis- $N$, anti-) and $\mathbf{B}\left(\right.$ exo-, cis- $N$, anti-) the phenyl ring of the 1- $\mathrm{PhC}_{3} \mathrm{H}_{4}$ ligand is on an anti- position in relation to the $\mathrm{C}^{\beta}-\mathrm{H}^{\beta}$ bond. The (endo-, cis- $N$, anti-) isomer $(\mathbf{B})$ has the highest $E_{T}$ of the set, this can be due to steric effects arising from the proximity of two bulky groups: the phenyl ring attached to the allyl unit and the bicyclic system of the N-donor ligand.

We also calculated the Boltzmann's distribution using the calculated energies at $182 \mathrm{~K}$ and $298 \mathrm{~K}$. Results reveal that at $182 \mathrm{~K}$ only isomers A, E and to a minor extent also isomer C (endo-, trans- $N$, syn) had relevant contributions ( 49,49 and $2 \%$, respectively). NMR studies at $182 \mathrm{~K}$ indicated: (a) the coexistence of two isomers (in molar ratios ranging from 1.0:0.6 to 1.00:0.8) and small amounts of other minor species; (b) that in the major components the arrangement of the $\mathrm{C}^{\alpha}$ carbon of the allyl and the nitrogen occupied adjacent positions $(c i s-N)$, the phenyl ring of the allyl unit was in the syn- site and differed in the conformation (exo- or endo-) of the 1- $\mathrm{PhC}_{3} \mathrm{H}_{5}$ ligand that is to say corresponding to isomers $\mathbf{A}$ and $\mathbf{E}$. That is consistent with the results obtained from the computational studies. On this basis we assume that the minor specie present in $\mathrm{CH}_{2} \mathrm{Cl}_{2}$ solutions at $182 \mathrm{~K}$ is isomer $\mathrm{C}$ (endo-, trans- $N$, syn-).

When Boltzmann's population analyses was carried out at $298 \mathrm{~K}$ (Table S9): contributions of the major isomers A (endo-, cis- $N$, syn-) and E (exo-, cis- $N$, syn-) decreased (from $49 \%$ to $46 \%$ ) that of $\mathbf{C}$ (endo-, trans- $N$, syn-) increased (from $2 \%$ to $6 \%$ ) and isomer G (exo-, trans- $N$, syn-), with no participation in the isomeric distribution at $182 \mathrm{~K}$ had also a tiny contribution. It is interesting to point out that changes on location of the nitrogen atom in relation to the $\mathrm{C}^{\alpha}$ carbon of the allyl ligand (cis- in $\mathbf{A}$ and $\mathbf{E}$ and trans- in $\mathbf{C}$ and $\mathbf{G}$ ) may introduce significant changes in the distribution of charge. In order to get further information on this problem, molecular orbital (MO) calculations for the optimized geometries of isomers A-H were analyzed. In all cases, (Table S10) the HOMO-1 and HOMO orbitals are centered on the $\mathrm{Cl}^{-}$ligand with a tiny contribution of the $\mathrm{Pd}(\mathrm{II})$ atom; while the LUMO is mainly a MO of the 2-phenyl substituted 3- $H$ indole ligand. In contrast, the LUMO+1, has a relevant contribution 
of the 1- $\mathrm{PhC}_{3} \mathrm{H}_{4}$ ligand. This molecular orbital would be involved in the nucleophilic attack, that is expected to occur in the more electrophilic site. In view of this and in order to fulfill this study we also undertook a comparative analysis of the charge distribution on the $\mathrm{C}^{\alpha}-\mathrm{C}^{\gamma}$ carbon atoms of the allyl ligand for the eight isomers. As shown in Table S11, for the major isomers (A and E) the orientation of the allyl group does not introduce significant variations in the charge distribution of the $\mathrm{C}^{\alpha}-\mathrm{C}^{\gamma}$ carbon atoms and the values are very similar to those obtained for the pair of isomers $\mathbf{C}$ and $\mathbf{G}$, and therefore this approach did not bring any valuable information on the proclivity of the terminal or substituted carbon atoms $\left(\mathrm{C}^{\alpha}\right.$ and $\left.\mathrm{C}^{\gamma}\right)$ to undergo the nucleophilic attack and therefore to explain the preferential formation of the lineal product (4) versus the branched derivative (5).

More interesting were the results obtained from the analyses of the fragment charges obtained from Natural Population analysis. As shown in Table S12, for the two major isomers (A and $\mathbf{E}$ with an abundance of ca. $46 \%$ each determined according to Boltzmann's distribution at $298 \mathrm{~K}$ ), the charge of the terminal $\mathrm{CH}_{2}$ unit is positive and very similar for both isomers, while that of the $\mathrm{CH}$ unit is clearly negative. In view of this, the nucleophilic attack is expected to occur on the $\mathrm{CH}_{2}$ unit, leading to the linear product. In isomers $\mathbf{C}$ and $\mathbf{G}$ with a trans- $\mathrm{C}^{\gamma}, N$ arrangement, opposite orientation of the allyl ligand and calculated abundancies of $6 \%$ and $2 \%$, respectively at $298 \mathrm{~K}$ ), the differences on the charges of these two fragments are not as spectacular as for the pair (A, E). However, for the couple ( $\mathbf{C}$ and $\mathbf{D}$ ) the charge of the $\mathrm{CH}_{2}$ fragment is smaller than for their partners ( $\mathbf{A}$ and $\mathbf{E}$ ) and that of the $\mathrm{CHPh}$ unit follows the opposite trend. In fact, the values obtained for isomer $\mathbf{G}$ suggest that the $\mathrm{CHPh}$ unit may be more prone to undergo the nucleophilic attack than the $\mathrm{CH}_{2}$. This would explain the formation of the branched derivative in both the stoichiometric and catalytic reactions. Compounds $\mathbf{3 b}$ and $\mathbf{3 c}$ are very similar to $\mathbf{3 a}$ except for the nature of the substituents on the indole unit, they exhibit a similar behavior in solution and therefore we assume that the conclusions reached for $3 a$ could also be extended to compounds $3 \mathbf{b}$ and $\mathbf{3 c}$.

\section{Experimental Section}

\subsection{Materials and Methods}

Ligands 1a-1c and the allylic compounds $\left[\mathrm{Pd}\left(\eta^{3}-1-\mathrm{R}^{3} \mathrm{C}_{3} \mathrm{H}_{4}\right)(\mu-\mathrm{Cl})\right]_{2}\left(\mathrm{R}^{3}=\mathrm{H}\right.$ or Ph) were prepared as described previously [21-24,36,37]. Sodium diethyl 2-methylmalonate (0.5 M in THF) was prepared from diethyl-2-methyl malonate and $\mathrm{NaH}$ in THF at $273 \mathrm{~K}$. The remaining reagents were obtained from Aldrich and used as received. The solvents were distilled and dried before use [50]. For the preparation of the complexes the reaction flasks were protected from the light with aluminum foil.

Elemental analyses (C, H, N) were performed in an EA-1108 CE Instruments (Thermo Fisher, Whaltham, MA, USA) apparatus at the Servei d'Anàlisi Elemental dels Centres Científics I Tecnològics (Univ. de Barcelona). Organometallic compounds were analyzed using $\mathrm{WO}_{3}$ or $\mathrm{SeO}$ as combustion catalysts. $\mathrm{ESI}^{+}$mass spectra were performed at the Servei d'Espectrometria de Masses (Univ. Barcelona) with a VG-Quattro Fisions instrument (Micromass Ltd., Wythenshawe, UK). IR spectra were obtained with a Nicolet 400-FTIR instrument (Thermo Fisher, Whaltham, MA, USA) using KBr pellets. Routine ${ }^{1} \mathrm{H}$ NMR spectra were obtained with a Mercury-400 instrument (Bruker Gmb, Mannheim, Germany). NMR spectra were recorded with a Varian VRX-500 (Palo Alto, CA, USA) or a Bruker Advance-DMX 500 instrument (Bruker Gmb, Mannheim, Germany) at $298 \mathrm{~K}$. The latter equipment was also used to perform the VT-NMR studies and to register the $\left[{ }^{1} \mathrm{H}-{ }^{1} \mathrm{H}\right]-\mathrm{NOESY}$ spectra at $182 \mathrm{~K}$. Characterization data for the new compounds are included as Supporting Information. 


\subsection{Preparation of the Compounds}

3.2.1. General Procedure for the Synthesis of Compounds $\left[\mathrm{Pd}\left(\eta^{3}-\mathrm{C}_{3} \mathrm{H}_{5}\right)\left\{\mathrm{C}_{8} \mathrm{H}_{3} \mathrm{~N}-2-\left(\mathrm{C}_{6} \mathrm{H}_{4}-4-\mathrm{R}^{1}\right)-3-\right.\right.$ NOMe-5- $\left.\mathrm{R}^{2}\right\} \mathrm{Cl}$ ] [with $\mathrm{R}^{1}=\mathrm{H}, \mathrm{R}^{2}=\mathrm{OMe}(\mathbf{2} \mathbf{a}) ; \mathrm{R}^{1}=\mathrm{R}^{2}=\mathrm{H}(\mathbf{2} \mathbf{b})$ or $\mathrm{R}^{1}=\mathrm{Cl}, \mathrm{R}^{2}=\mathrm{H}$ (2c)]

$\left[\mathrm{Pd}\left(\eta^{3}-\mathrm{C}_{3} \mathrm{H}_{5}\right)(\mu-\mathrm{Cl})\right]_{2}\left(100 \mathrm{mg}, 2.73 \times 10^{-4} \mathrm{~mol}\right)$ was treated with $\mathrm{CH}_{2} \mathrm{Cl}_{2}(\mathrm{ca} .5 \mathrm{~mL})$. Then this solution was added to another one solution by $5.47 \times 10^{-4} \mathrm{~mol}$ of the corresponding ligand $(148,129$ or $149 \mathrm{mg}$ for 1a-1c, respectively) in the minimum amount of $\mathrm{CH}_{2} \mathrm{Cl}_{2}$. The resulting reaction mixture was stirred at $298 \mathrm{~K}$ during $1 \mathrm{~h}$. After this period the undissolved materials were filtered, and the filtrate was concentrated to dryness on a rotary evaporator. The isolated residue was afterwards dissolved in $\mathrm{CH}_{2} \mathrm{Cl}_{2}(3 \mathrm{~mL})$. Addition of $n$-hexane $(\approx 3 \mathrm{~mL})$ followed by slow evaporation of the solvents at $298 \mathrm{~K}$ produced crystals of $\mathbf{2} \mathbf{a}$ and microcrystalline solids for $\mathbf{2} \mathbf{b}$ and $\mathbf{2} \mathbf{c}$, that later on were collected, air-dried and afterwards dried in vacuum for 2 days. Yield: $209 \mathrm{mg}$ (85\%), $204 \mathrm{mg}(89 \%)$ and $212 \mathrm{mg}$ (85\%) for $2 \mathbf{a}, \mathbf{2 b}$ and $\mathbf{2 c}$, respectively.

3.2.2. General Procedure for the Synthesis of Compounds [Pd( $\left(\eta^{3}-1-\mathrm{PhC}_{3} \mathrm{H}_{4}\right)\left\{\mathrm{C}_{8} \mathrm{H}_{3} \mathrm{~N}-2-\left(\mathrm{C}_{6} \mathrm{H}_{4}-4-\mathrm{R}^{1}\right)-3-\right.$ NOMe-5-R ${ }^{2}$ Cl] [with $\mathrm{R}^{1}=\mathrm{H}, \mathrm{R}^{2}=\mathrm{OMe}(3 \mathrm{a}) ; \mathrm{R}^{1}=\mathrm{R}^{2}=\mathrm{H}(3 \mathrm{~b})$ or $\mathrm{R}^{1}=\mathrm{Cl}, \mathrm{R}^{2}=\mathrm{H}$ (3c)]

A $1.74 \times 10^{-4} \mathrm{~mol}$ amount of the corresponding ligand $\{\mathbf{1 a}(46 \mathrm{mg}), \mathbf{1} \mathbf{b}(41 \mathrm{mg})$ or $\mathbf{1 c}(47 \mathrm{mg})$ was treated with $5 \mathrm{~mL}$ of $\mathrm{CH}_{2} \mathrm{Cl}_{2}$ and stirred at room temperature until complete dissolution. Then, this solution was added to another one formed by $45 \mathrm{mg}\left(8.69 \times 10^{-5} \mathrm{~mol}\right)$ of $\left[\mathrm{Pd}\left(\eta^{3}-1-\mathrm{PhC}_{3} \mathrm{H}_{4}\right)(\mu-\mathrm{Cl})\right]_{2}$ in the minimum amount of $\mathrm{CH}_{2} \mathrm{Cl}_{2}$ (ca. $5 \mathrm{~mL}$ ) and the resulting reaction mixture was stirred at $298 \mathrm{~K}$ for $1 \mathrm{~h}$. After this period, it was filtered, and the red filtrate was concentrated to dryness on a rotatory evaporator. After cooling to room temperature, the gummy residue was treated with $\mathrm{CH}_{2} \mathrm{Cl}_{2}(2 \mathrm{~mL})$. Addition of diethyl ether (ca. $2 \mathrm{~mL}$ ) followed by evaporation of the solvents at $278 \mathrm{~K}$ produced crystals of $\mathbf{3 a}$ and $\mathbf{3 b}$ suitable for X-ray and a microcrystalline solid for 3c. Yields: $87 \mathrm{mg}(91 \%), 77 \mathrm{mg}(89 \%)$ or $84 \mathrm{mg}(91 \%)$ for $3 \mathrm{a}-3 \mathbf{c}$, respectively.

\subsection{Crystallography}

A prism-like specimens of $\mathbf{2} \mathbf{a}, \mathbf{3} \mathbf{a}$ or $\mathbf{3} \mathbf{b}$ (sizes in Table 1) were used for the X-ray crystallographic analysis. The $\mathrm{X}$-ray intensity data were measured on a MAR 355 system equipped with a graphite monochromator and a Mo- fine focus sealed tube $(\lambda=0.71073 \AA)$.

The frames were integrated with the MAR345 software package using a "MARSCALE" algorithm. The integration of data using a monoclinic (for $\mathbf{2 a}$ and $\mathbf{3 a}$ ) or a triclinic (for $\mathbf{3 b}$ ) unit cell yielded: for 2a a total of 3861 reflections to a maximum $\theta$ angle of $32.34^{\circ}$ ( $0.66 \AA$ resolution), of which 3861 were independent (average redundancy 1.000 , completeness $=58.7 \%, R_{\text {int. }}=5.43 \%, R_{\text {sig }}=3.98 \%$ ) and 3146 $(81.48 \%)$ were greater than $2 \sigma\left(\mathrm{F}^{2}\right)$; for $3 \mathbf{a}$ a total of 19380 reflections to a maximum $\theta$ angle of $30.88^{\circ}$ (0.69 A resolution), of which 5572 were independent (average redundancy 3.478 , completeness $=78.8 \%$, $\left.R_{\text {int. }}=2.5 \%, R_{\text {sig }}=1.71 \%\right)$ and $5338(95.80 \%)$ were greater than $2 \sigma\left(\mathrm{F}^{2}\right)$ and, for $3 \mathbf{b}$ a total of 18112 reflections to a maximum $\theta$ angle of $30.36^{\circ}$ ( $0.70 \AA$ resolution), of which 9882 were independent (average redundancy $=1.833$, completeness $=75.8 \%, R_{\text {int. }}=2.07 \%, R_{\text {sig }}=2.00 \%$ ) and $9033(91.41 \%)$ were greater than $2 \sigma\left(\mathrm{F}^{2}\right)$. The final cell constants (presented in Table 1) are based on the refinement of XYZ centroids of reflections above $20 \sigma(\mathrm{I})$. The calculated minimum and maximum transmission coefficients (based on crystal size) are: 0.8700 and 0.8900 for 2a, 0.8900 and 0.9100 (for 3a) and 0.5000 and 0.500 (for $3 \mathbf{b}$ ).

The structures were solved and refined with the SHELXTL computer program [51]. Final R factors and further details concerning the refinement of the structures of $\mathbf{2 a}, \mathbf{3} \mathbf{a}$ and $\mathbf{3} \mathbf{b}$ are summarized in Table 1.

CCDC-1492860-1492862 contain the supplementary crystallographic data for 2a, 3a and $\mathbf{3 b}$, respectively. These data can be obtained free of charge via hhtp://www.ccdc.cam.ac.uk/ 
const/retrieving.htlm or from the Cambridge Crystallographic Data Centre 12 Union Road, Cambridge CB2 1EZ, UK; fax (+44) 1223-336-033 or e-mail: deposit@ccdc.cam.ac.uk

\subsection{Typical Procedure for Allylic Alkylation}

The catalytic reactions were performed at $298 \mathrm{~K}$ in THF $(5 \mathrm{~mL})$ using $2.5 \times 10^{-3} \mathrm{mmol}$ of $\left[\mathrm{Pd}\left(\eta^{3}-\mathrm{C}_{3} \mathrm{H}_{5}\right)(\mu-\mathrm{Cl})\right]_{2}, 5.0 \times 10^{-3} \mathrm{mmol}$ of the corresponding ligand $\mathbf{1 a}-\mathbf{1 c}, 0.5 \mathrm{mmol}$ of cinnamyl acetate and $1.0 \mathrm{mmol}$ of sodium diethyl 2-methylmalonate. The reaction was monitored by taking samples from the reaction. Each aliquot was diluted in $\mathrm{Et}_{2} \mathrm{O}$, washed with $\mathrm{H}_{2} \mathrm{O}$, dried over $\mathrm{MgSO}_{4}$ and then analyzed by GC using decane $(0.258 \mathrm{mmol})$ as internal standard.

The product distribution of the alkylation experiments was measured on an Interscience Mega2 or Trace-DQS apparatus. The Interscience Mega2 was equipped with a DB1 column, length $30 \mathrm{~m}$, inner diameter $0.32 \mathrm{~mm}$, a film thickness of $3.0 \mu \mathrm{m}$, and a flame ionization detector. The Trace-DQS instrument had a HP- 5 column ( $25 \mathrm{~m}$ in length, $0.5 \mu \mathrm{m}$ film thickness, and $0.2 \mathrm{~mm}$ inner diameter $)$ and was equipped with an electron impact mass detector.

These studies were performed under nitrogen. The stoichiometric alkylation reaction of $\mathbf{3 a}$ and $\mathbf{3 c}$ were performed at $298 \mathrm{~K}$ by adding an excess of sodium diethyl-2-methylmalonate $(0.8 \mathrm{~mL}$ of a $0.5 \mathrm{M}$ solution in THF) to a solution containing $3 \mathrm{a}\left(57 \mathrm{mg}, 1.10 \times 10^{-4} \mathrm{~mol}\right)$ or $3 \mathrm{c}\left(58 \mathrm{mg}, 1.08 \times 10^{-4} \mathrm{~mol}\right)$. The reaction was instantaneous, and $\mathrm{H}_{2} \mathrm{O}$ was added after $10 \mathrm{~min}$. The reaction mixture was filtered over Celite. The filtrate was then treated with $\mathrm{Et}_{2} \mathrm{O}(\sim 15 \mathrm{~mL})$, and the organic layer was washed with $\mathrm{H}_{2} \mathrm{O}$ $\left(3 \times 3 \mathrm{~mL}\right.$ portions). The organic phase was dried over $\mathrm{MgSO}_{4}$, and the filtrate was concentrated to dryness on a rotary evaporator. The residue was dissolved in a minimum amount of $\mathrm{Et}_{2} \mathrm{O}$ and passed through a short $\mathrm{SiO}_{2}$ column $(4.0 \mathrm{~cm} \times 0.6 \mathrm{~cm})$. The band released was collected and concentrated to dryness. The oily residue isolated contained, according to ${ }^{1} \mathrm{H}$ NMR (500 MHz) and GC compounds 4 and 5 in molar ratios 98.3:1.7 for 3a and 99.4:0.6 for 3c.

\subsection{Computational Studies}

DFT calculations of compound $\left[\mathrm{Pd}\left(\eta^{3}-1-\mathrm{PhC}_{3} \mathrm{H}_{4}\right)\left\{\mathrm{C}_{8} \mathrm{H}_{3} \mathrm{~N}-2-\left(\mathrm{C}_{6} \mathrm{H}_{4}-4-\mathrm{R}^{1}\right)-3-\mathrm{NOMe}-5-\mathrm{R}^{2}\right\} \mathrm{Cl}\right\}$ [with $\mathrm{R}^{1}=\mathrm{H}, \mathrm{R}^{2}=\mathrm{OMe}$ and $\mathrm{R}^{3}=\mathrm{Ph}(\mathbf{3 a})$ ], were carried out using the Gaussian09 package [48] and the B3LYP functional $[45,46]$. Effective core potentials (ECP) were used to represent the innermost electrons of the palladium atom and the basis set of valence double- $\zeta$ quality for associated with the pseudopotentials known as LANL2DZ [47]. The basis set for the main group elements $(\mathrm{Cl}, \mathrm{P}, \mathrm{C}, \mathrm{N}, \mathrm{O}$ and $\mathrm{H})$ was 6-31G* [52,53]. Solvent effects of dichloromethane were taken into account by PCM calculations [49], keeping the geometry optimized for gas phase (single-point calculations).

\section{Conclusions}

Two new families of $\mathrm{Pd}(\mathrm{II})$-allyl complexes containing simultaneously the 2-phenyl-3H-indoles $\mathrm{C}_{8} \mathrm{H}_{3} \mathrm{~N}-2-\left(\mathrm{C}_{6} \mathrm{H}_{4}-4-\mathrm{R}^{1}\right)-3-\mathrm{NOMe}-5-\mathrm{R}^{2}(\mathbf{1})\left[\mathrm{R}^{1}=\mathrm{H}, \mathrm{R}^{2}=\mathrm{OMe}(\mathbf{a})\right.$ or $\mathrm{H}(\mathbf{b})$ or $\left.\mathrm{R}^{1}=\mathrm{Cl}, \mathrm{R}^{2}=\mathrm{H}(\mathbf{c})\right]$ and the allyl ligands $\left(\eta^{3}-1-\mathrm{R}^{3} \mathrm{C}_{3} \mathrm{H}_{4}\right)$ with $\mathrm{R}^{3}=\mathrm{H}(\mathbf{2 a}-\mathbf{2 c})$ or $\mathrm{Ph}(\mathbf{3 a}-\mathbf{3 c})$ have been prepared and characterized in the solid state and also in solution. In the new compounds ligands 1a-1c bind to the $\operatorname{Pd}(\mathrm{II})$ through the indole ligand and the $X$-ray diffraction studies of $\mathbf{2} \mathbf{a}, \mathbf{3} \mathbf{a}$ and $\mathbf{3} \mathbf{b}$, confirmed this finding and allowed the identification of the isomer present in the crystals [endo- in $\mathbf{2 a}$ or (exo-, cis- $\mathrm{N}, \mathrm{syn}-)$ in $\mathbf{3} \mathbf{a}$ and also in the two different molecules (I and II) found in the crystals of $\mathbf{3 b}$. VT ${ }^{1} \mathrm{H}-\mathrm{NMR}$ studies of $\mathrm{CD}_{2} \mathrm{Cl}_{2}$ solutions of the compounds in the range 298-182 K, provided conclusive evidence of the coexistence of several isomers in solution. At $182 \mathrm{~K}^{1} \mathrm{H}-\mathrm{NMR}$ spectra of $\mathbf{2 a - 2} \mathbf{c}$ suggested the presence of two isomers that differ in the relative arrangement of the central $\mathrm{CH}$ bond of the allyl and the phenyl ring of the indole scafold (endo- or exo-). The solution behavior of compounds 3a-3c is more complex and even at 182 $\mathrm{K}$ their ${ }^{1} \mathrm{H}-\mathrm{NMR}$ spectra showed several superimposed signals indicating the presence of two major components in solution and also small amounts $(<10 \%)$ or even traces of other isomers.

Additional studies carried out at $298 \mathrm{~K}$ on: a) the catalytic activity of mixtures containing $\left[\mathrm{Pd}\left(\eta^{3}-\mathrm{C}_{3} \mathrm{H}_{5}\right)(\mu-\mathrm{Cl})\right]_{2}$ and the parent ligand $(\mathbf{1 a}-\mathbf{1 c})$ in the allylic alkylation of $(E)$-3-phenyl-2-propenyl 
(cinnamyl) acetate with sodium diethyl 2-methylmalonate, and b) the stoichiometric reaction between $3 \mathbf{a}$ or $3 \mathbf{c}$ and the nucleophile give the linear trans- derivative (4) preferentially over the branched product (5). The computational studies carried out with compound $3 \mathbf{a}$ as a representative model of the series, have allowed us to determine the relative stabilities of all its isomers in $\mathrm{CD}_{2} \mathrm{Cl}_{2}$ and their relative abundances at $298 \mathrm{~K}$ and $182 \mathrm{~K}$. The results obtained agree with those obtained from the VT-NMR studies. Moreover, the comparison of the charges on the main fragments of the allyl group of $3 \mathbf{a}$, shows that in the major isomers $\{e n d o-($ or exo-), cis- $\mathrm{N}$, syn-, $\mathbf{A}$ and $\mathbf{E}$ in Figure 3)\} present at $182 \mathrm{~K}$ and also at $298 \mathrm{~K}$, the charge on the $\mathrm{CH}_{2}$ unit is higher than that of the $\mathrm{CHPh}$ at the other end, and therefore more susceptible to undergo the attack by the nucleophile to produce the linear trans-compound (4). The catalytic studies and the stoichiometric reactions were performed at $298 \mathrm{~K}$, according to Boltzmann's distribution at this temperature isomers $\{e n d o-($ or exo-), trans- $N$, syn- $\}, \mathbf{C}$ and $\mathbf{G}$, in Figure 3, that arise from $\mathbf{A}$ and $\mathbf{E}$ respectively by a cis- $N \rightarrow$ trans- $N$ isomerization process, are also present in solution. In $\mathbf{C}$ and $\mathbf{G}$ isomers, the charges of the $\mathrm{CH}_{2}$ and $\mathrm{CHPh}$ units decrease and increase, respectively in relation to those of the major components ( $\mathbf{A}$ and $\mathbf{E}$ ). This finding could explain the attack of the nucleophile to the "CHPh" unit of the allyl unit to give the branched derivative (5).

To sum up, the studies in this work show the utility of 2-substituted-3H-indole ligands and their $\operatorname{Pd}(\mathrm{II})$ allyl complexes in the allylic alkylation of (E)-3-phenyl-2-propenyl (cinnamyl) acetate with sodium diethyl 2-methylmalonate. The results presented here constitute the first step of a new research area focused on other $\mathrm{C}-\mathrm{X}$ bond formation processes (i.e. allylic aminations). Moreover, and according to the computational studies, the relative arrangement of the $N_{\text {indole }}$ atom and the $\mathrm{CHPh}$ unit of the allyl group (cis- or trans-), produces significant variations in the electrophilicity of these arrays. On these basis, the replacement of the hydrogen atoms on positions 3 (or 4 ) of the bicyclic system by bulkier substituents may introduce significant steric hindrance as to modify the relative arrangement of the $\alpha$-carbon of the 1- $\mathrm{PhC}_{3} \mathrm{H}_{4}$ ligand and the donor nitrogen, the charges on the terminal carbon atoms, and therefore to tune the regioselectivity of the processes towards the branched derivative. Further work in this area is on the way.

Supplementary Materials: An additional file (available at http://www.mdpi.com/2073-4344/9/10/811/s1) containing: 1. Characterization data for the new compounds: elemental analyses, mass spectrometry data, selected bands observed in the IR spectra and ${ }^{1} \mathrm{H}$ and ${ }^{13} \mathrm{C}\left\{{ }^{1} \mathrm{H}\right\}-\mathrm{NMR}$ data for compounds: $\left[\mathrm{Pd}\left(\eta^{3}-\mathrm{C}_{3} \mathrm{H}_{5}\right)\right.$ $\left\{\mathrm{C}_{8} \mathrm{H}_{3} \mathrm{~N}-2-\left(\mathrm{C}_{6} \mathrm{H}_{4}-4-\mathrm{R}^{1}\right)-3-\mathrm{NOMe}-5-\mathrm{R}^{2}\right\} \mathrm{Cl}$ ] [with $\mathrm{R}^{1}=\mathrm{H}, \mathrm{R}^{2}=\mathrm{OMe}(\mathbf{2} \mathbf{a}) ; \mathrm{R}^{1}=\mathrm{R}^{2}=\mathrm{H}(\mathbf{2 b})$ or $\mathrm{R}^{1}=\mathrm{Cl}_{1} \mathrm{R}^{2}=\mathrm{H}$ (2c)] and $\left[\mathrm{Pd}\left(\eta^{3}-1-\mathrm{PhC}_{3} \mathrm{H}_{4}\right)\left\{\mathrm{C}_{8} \mathrm{H}_{3} \mathrm{~N}-2-\left(\mathrm{C}_{6} \mathrm{H}_{4}-4-\mathrm{R}^{1}\right)-3-\mathrm{NOMe}-5-\mathrm{R}^{2}\right\} \mathrm{Cl}\right.$ ] [with $\mathrm{R}^{1}=\mathrm{H}, \mathrm{R}^{2}=\mathrm{OMe}(3 \mathbf{a}) ; \mathrm{R}^{1}=\mathrm{R}^{2}=\mathrm{H}$ (3b) or $\left.\mathrm{R}^{1}=\mathrm{Cl}, \mathrm{R}^{2}=\mathrm{H}(3 \mathbf{c})\right]$ together with the chemical formulae of the major isomers present in solution. 2. Supplementary Figures (Figures S1-S15): Figure S1. Simplified views of structures of the molecules found in the crystals of compounds $\mathbf{2 a}, \mathbf{3 a}$ and $\mathbf{3 b}[\mathbf{a} \mathbf{a}-\mathbf{( c )}$, respectively]. Figure S2. Simplified view of the assembly of molecules of $\mathbf{2 a}$ in the crystals by two co-operative $\mathrm{C}-\mathrm{H} \cdots \mathrm{O}$-O short contacts (red dotted lines) involving the C17-H17B bond of a molecule and the $\mathrm{O} 1$ atom of another unit and viceversa. Figure S3. Schematic view of the intramolecular $\mathrm{C}-\mathrm{H} \cdots \mathrm{O} 2, \mathrm{C}-\mathrm{H} \cdots \mathrm{N} 2$ short contacts and the "cooperative" assembly of two molecules of 3a by intermolecular $\mathrm{C} 18-\mathrm{H} 18 \cdots \mathrm{Cl} 1$ interactions, forming dimers. Figure S4. Schematic view of the intramolecular C-H $\cdots \mathrm{O}$ short contacts in molecules I and II of compound $3 \mathbf{b}$, and the intermolecular $\mathrm{CH} \cdots \mathrm{Cl}$ short contacts and $\mathrm{C}-\mathrm{H} \cdots \pi$ interactions. Figure S5. ${ }^{1} \mathrm{H}-\mathrm{NMR}$ spectra $(500 \mathrm{MHz})$ of compound $\left[\mathrm{Pd}\left(\eta^{3}-\mathrm{C}_{3} \mathrm{H}_{5}\right)\left\{\mathrm{C}_{8} \mathrm{H}_{3} \mathrm{~N}-2-\left(\mathrm{C}_{6} \mathrm{H}_{4}-4-\mathrm{R}^{1}\right)-3-\mathrm{NOMe}-5-\mathrm{R}^{2}\right\} \mathrm{Cl}\right]$ (with $\left.\mathrm{R}^{1}=\mathrm{H}, \mathrm{R}^{2}=\mathrm{OMe}\right), 2 \mathrm{a}$ in $\mathrm{CD}_{2} \mathrm{Cl}_{2}$ at $\mathrm{T}=298 \mathrm{~K}$ and $273 \mathrm{~K}$. Figure S6. ${ }^{1} \mathrm{H}-\mathrm{NMR}$ spectra of compound $\mathbf{2 b}$ in $\mathrm{CD}_{2} \mathrm{Cl}_{2}$ at $\mathrm{T}=298 \mathrm{~K}$ and $273 \mathrm{~K}$. Figure S7. ${ }^{1} \mathrm{H}-\mathrm{NMR}$ spectra of $2 \mathrm{c}$ in $\mathrm{CD}_{2} \mathrm{Cl}_{2}$ at $\mathrm{T}=298 \mathrm{~K}$ and $273 \mathrm{~K}$. Figure S8. Partial views of the ${ }^{1} \mathrm{H}-\mathrm{NMR}$ spectrum of $2 \mathrm{a}$ in $\mathrm{CD}_{2} \mathrm{Cl}_{2}$ at $182 \mathrm{~K}$, showing the presence of two sets of superimposed signals suggesting the presence of two isomers [ $2 \mathbf{a}_{I}$ and $2 \mathbf{a}_{I I}$ (major and minor components, respectively)]. The resonances due to the allylic protons of $\mathbf{2} \mathbf{a}_{\mathbf{I}}$ are labelled as I; while those of $\mathbf{2} \mathbf{a}^{\mathrm{II}}$ as II. Figure S9. Partial views or the ${ }^{1} \mathrm{H}-\mathrm{NMR}$ spectrum of $\mathbf{2 b}$ in $\mathrm{CD}_{2} \mathrm{Cl}_{2}$ at $182 \mathrm{~K}$, showing the presence of two sets of superimposed signals suggesting the presence of two isomers [ $2 \mathbf{b}^{\mathbf{I}}$ and $\mathbf{2} \mathbf{b}^{\mathbf{I I}}$ (major and minor components, respectively)]. The resonances due to the allylic protons of $\mathbf{2} \mathbf{b}^{\mathbf{I}}$ are labelled as I; while those of $\mathbf{2} \mathbf{b}_{\text {II }}$ as II. Figure S10. Partial views or the ${ }^{1} \mathrm{H}-\mathrm{NMR}$ spectrum of $2 \mathrm{c}$ in $\mathrm{CD}_{2} \mathrm{Cl}_{2}$ at $182 \mathrm{~K}$, showing the presence of two sets of superimposed signals suggesting the presence of two isomers [ $2 \mathbf{c}^{\mathrm{I}}$ and $2 \mathbf{c}^{\mathrm{II}}$ (major and minor components, respectively]. The resonances due to the allylic protons of $2 \mathbf{c}^{\mathbf{I}}$ are labelled as $\mathbf{I}$; while those of $2 \mathbf{c}_{\text {II }}$ as II. Figure S11. ${ }^{1} \mathrm{H}-\mathrm{NMR}$ spectra of $\mathbf{3 a}$ in $\mathrm{CD}_{2} \mathrm{Cl}_{2}$ at $298 \mathrm{~K}$ (top), $273 \mathrm{~K}$ (middle) and $182 \mathrm{~K}$ (bottom). Partial views of the spectrum registered at $182 \mathrm{~K}$ are shown as insets to illustrate the presence of several sets of superimposed signals of which those labelled as I and II correspond to the two major isomers (hereinafter referred to as $3 \mathbf{a}^{\mathbf{I}}$ and $3 \mathbf{a}^{\mathbf{I I}}$ ) present in solution. Figure S12. ${ }^{1} \mathrm{H}-\mathrm{NMR}$ spectrum of compound $3 \mathrm{c}$ in $\mathrm{CD}_{2} \mathrm{Cl}_{2}$ at $182 \mathrm{~K}$, showing, the presence of two sets of superimposed signals due to isomers 
$3 \mathbf{a}^{\mathrm{I}}$ and $3 \mathrm{a}^{\mathrm{II}}$ (major and minor components, respectively), with high abundance. Other minor peaks labelled as III, suggest the co-existence of an additional isomer (3a $\mathbf{a}^{\text {III }}$ ) (top) and $\left[{ }^{1} \mathrm{H}_{-}{ }^{1} \mathrm{H}\right]$-NOESY spectrum of $3 \mathbf{a}$ at $182 \mathrm{~K}$ in $\mathrm{CD}_{2} \mathrm{Cl}_{2}$ (bottom). Figure S13. ${ }^{1} \mathrm{H}-\mathrm{NMR}$ spectrum of $3 \mathbf{b}$ in $\mathrm{CD}_{2} \mathrm{Cl}_{2}$ at $182 \mathrm{~K}$, showing the presence of two isomers ( $3 \mathbf{b}^{\mathrm{I}}$ and $\mathbf{3} \mathbf{b}^{\mathbf{I I}}$ (major and minor components, respectively), with high abundance. Figure S14. Partial view of the ${ }^{1} \mathrm{H}-\mathrm{NMR}$ spectrum of $3 \mathrm{c}$ in $\mathrm{CD}_{2} \mathrm{Cl}_{2}$ at $182 \mathrm{~K}$, the presence of two isomers ( $3 \mathrm{c}^{\mathrm{I}}$ and $3 \mathrm{c}^{\mathrm{II}}$ (major and minor components, respectively), with high abundance. Figure S15. Optimized geometries of the eight isomers (A-H) of compound 3a. 3. Supplementary Tables (S1-S11): Table S1. Final atomic coordinates of the optimized geometry of the endo-, cis-N, syn- isomer of 3a (type A in Figure 3 and Figure S15). Table S2. Final atomic coordinates of the optimized geometry of the endo-, cis-N, anti- isomer of compound 3a (type B in Figure 3 and Figure S15). Table S3. Final atomic coordinates of the optimized geometry of the isomer endo-, trans- $N$, syn-isomer of compound 3a (type C in Figure 3 and Figure S10). Table S4. Final atomic coordinates of the optimized geometry of isomer endo-, trans- $N$, anti-isomer of compound 3a (type D in Figure 3 and Figure S15). Table S5. Final atomic coordinates of the optimized geometry of the exo-, cis-N, syn- isomer of 3a (type E in Figure 3 and Figure S15). Table S6. Final atomic coordinates of the optimized geometry of the exo-, cis- $N$, anti-isomer of compound 3a (type F in Figure 3 and Figure S15). Table S7. Final atomic coordinates of the optimized geometry of the isomer exo-, trans- $N$, synisomer of compound 3a (type $\mathbf{G}$ in Figure 3 and Figure S15). Table S8. Final atomic coordinates of the optimized geometry of isomer exo-, trans- $N$, anti- isomer of compound 3a (type $\mathbf{H}$ in Figure 3 and Figure S15). Table S9. Summary of the characteristic of the isomers $(\mathbf{A}-\mathbf{H})$ of 3 a together with calculated electronic energies in $\mathrm{CH}_{2} \mathrm{Cl}_{2}$, the variation of the calculated energies in relation to the most stable isomer $(\Delta E)$ and the results obtained from the Botlzmann's distribution at $298.15 \mathrm{~K}$ and $182.0 \mathrm{~K}$. Table S10. Atomic composition of frontier molecular orbitals and energies (au) for isomers A-H of compound 3a. Table S11. Fragment charges, from the Natural Population analysis for isomers $\mathbf{A}-\mathbf{H}$ of compound 3a.

Author Contributions: All the authors contribute equally except for the X-ray diffraction studies. (M.F.B. and T.C.)

Funding: This research was funded by Ministerio de Ciencia e Innovación of Spain, Grants: CTQ2015-65040P (subprogram BQU) and PGC2018-093863-B-C21.

Conflicts of Interest: The authors declare no conflict of interest.

\section{References}

1. Gribble, W. Heterocyclic Scaffolds II: Reactions and Applications of Indoles, Topics in Heterocyclic Chemistry; Book Series; Springer: Berlin, Germany, 2010; Volume 26. [CrossRef]

2. Nylund, K.; Johansson, P. Heterocyclic Compounds: Synthesis, Properties and Applications; Chemistry Research and Applied Series; Nova Science Publishers Inc.: Hauppauge, NY, USA, 2010; ISBN 10: 1608763684.

3. Ghinea, I.O.; Dinica, R.D. Breakthoughts in Indole and Indolizine Chemistry, New Synthetic Pathways, New Applications, in Scope of Selective Heterocycles from Organic and Pharmaceutical Perspective; Varala, V., Ed.; IntechOpen: Rijeka, Croatia, 2016; Chapter 5; pp. 1043-1561. [CrossRef]

4. Sonsona, I.G. Indole, a Privileged Structural Core Motif. Synlett 2015, 26, 2325-2326. [CrossRef]

5. Ziarani, G.M.; Moradi, R.; Ahmadi, T.; Lashgar, N. Recent advances in the application of indoles in multicomponent reactions. RSC Adv. 2018, 8, 12069-12103. [CrossRef]

6. Ila, H.; Markiewicz, J.T.; Malakhov, V.; Knochel, P. Metalated Indoles, Indazoles, Benzimidazoles, and Azaindoles and Their Synthetic Applications. Synthesis 2013, 45, 2343-2371. [CrossRef]

7. Bandini, M. Electrophilicity: The "dark-side" of indole chemistry. Org. Biomol. Chem. 2013, 11, 5206-5212. [CrossRef] [PubMed]

8. Kaushik, N.; Kaushik, N.; Attri, P.; Kumar, N. Biomedical Importance of Indole. Molecules 2013, 18, 6620-6666. [CrossRef] [PubMed]

9. Abbey, E.R.; Liu, S.-Y. BN isosteres of indole. Org. Biomol. Chem. 2013, 11, 2060-2069. [CrossRef] [PubMed]

10. Bhat, M.A.; Al-Omar, M.A.; Raish, M.; Ansari, M.A.; Abuelizz, H.A.; Bakheit, A.H.; Naglah, A.M. Indole Derivatives as Cyclooxygenase Inhibitors: Synthesis, Biological Evaluation and Docking Studies. Molecules 2018, 23, 1250. [CrossRef] [PubMed]

11. Sidhu, J.S.; Singla, R.; Mayank, J.V. Indole Derivatives as Anticancer Agents for Breast Cancer Therapy: A Review. Anti-Cancer Agents Med. Chem. 2016, 16, 160-173. [CrossRef]

12. Mollica, A.; Locatelli, M.; Stefanucci, A.; Pinnen, F. Synthesis and Bioactivity of Secondary Metabolites from Marine Sponges Containing Dibrominated Indolic Systems. Molecules 2012, 17, 6083-6099. [CrossRef]

13. Venkateswararao, A.; Tyagi, P.; Justin, T.K.R.; Chen, P.-W.; Ho, K.-C. Organic dyes containing indolo [2, 3-b]quinoxaline as a donor: Synthesis, optical and photovoltaic properties. Tetrahedron 2014, 70, 6318-6327. [CrossRef] 
14. Babu, D.D.; Gachumale, S.R.; Anandan, S.; Adhikari, A.V. New D- $\pi$-A type indole based chromogens for DSSC: Design, synthesis and performance studies. Dyes Pigments 2015, 112, 183-191. [CrossRef]

15. Makosza, M.; Wojciechowski, K. Synthesis of Heterocycles via Nucleophilic Substitution of Hydrogen in Nitroarenes. Heterocycles 2014, 88, 75-101. [CrossRef]

16. Zhuo, D.; Sun, J.; Yan, C.G. One-pot synthesis of 6, 11-dihydro-5H-indolizino[8,7-b]indoles via sequential formation of $\beta$-enamino ester, Michael addition and Pictet-Spengler reactions. RSC Adv. 2014, 4, 62817-62828. [CrossRef]

17. Gosh, S.K.; Nagaraya, R. Total synthesis of cruciferane via epoxidation/tandem cyclization sequence. RSC Adv. 2014, 4, 63147-63149. [CrossRef]

18. Shimazaki, Y.; Yajima, T.; Takani, M.; Yamauch, O. Metal complexes involving indole rings, structures and effects of metal-indole interactions. Coord. Chem Rev. 2009, 253, 479-492. [CrossRef]

19. Khaledi, H.; Ali, H.M.; Olmstead, M.M. Versatile Coordination Modes of 2-(Diformylmethylene)3,3-dimethylindole towards Late-Transition-Metal Ions: C-H Bond Activation and Formation of Cyclic Acyl-Palladium(II) Complexes. Eur. J. Inorg. Chem. 2011, 2011, 2394-2404. [CrossRef]

20. Khaledi, H.; Olmstead, M.M.; Ali, H.M.; Thomas, N.F. Indolenine meso-Substituted Dibenzotetra-aza[14] annulene and Its Coordination Chemistry toward the Transition Metal Ions MnIII, FeIII, CoII, NiII, CuII, and PdII. Inorg. Chem. 2013, 52, 1926-1941. [CrossRef]

21. Tomé, M.; López, C.; González, A.; Ozay, B.; Quirante, J.; Font-Bardía, M.; Calvet, T.; Calvis, C.; Messeguer, R.; Baldomà, L.; et al. Trans-and cis-2-phenylindole platinum(II) complexes as cytotoxic agents against human breast adenocarcinoma cell lines. J. Mol. Struct. 2013, 1048, 88-97. [CrossRef]

22. Belsa, L.; López, C.; González, A.; Font-Bardía, M.; Calvet, T.; Calvis, C.; Messeguer, R. Neutral and Ionic Cycloruthenated 2-Phenylindoles as Cytotoxic Agents. Organometallics 2013, 32, 7264-7267. [CrossRef]

23. López, C.; González, A.; Moya, C.; Bosque, R.; Solans, X.; Font-Bardía, M. Cyclopalladation of 3-methoxyimino-2-phenyl-3H-indoles. J. Organomet. Chem. 2008, 693, 2877-2886. [CrossRef]

24. Li, J.J.; Gribble, G.W. Palladium in Heterocyclic Chemistry; Pergamon: New York, NY, USA, 2000.

25. Joule, J.A.; Mills, K. Heterocyclic Chemistry at a Glance; Chapters 4 Palladium in Heterocyclic Chemistry; Chapters 10 Indoles; Wiley: Hoboken, NJ, USA, 2012; pp. 21-32, 86-98. [CrossRef]

26. Trost, B.M. Catalysis: Unlimited frontiers. Our early personal journey into the world of palladium, Topics in Organometallic Chemistry. In Inventing Reactions; Springer: Heildelberg, Germany, 2013; Volume 44, pp. 1-12. [CrossRef]

27. Brase, S. Organopalladium Chemistry, in Organometallics in Synthesis: Third Manual; Schlosser, M., Ed.; John Wiley \& Sons: Hoboken, NJ, USA, 2013; pp. 777-1000. [CrossRef]

28. Crabtree, R.H.; Mingos, D.P. Comprehensive Organometallic Chemistry; Elsevier Ltd: Oxford, UK, 2007; Volume 8, Chapter 6; pp. 358-371.

29. Canovese, L.; Visentin, F.; Levi, C.; Dolmella, A. Synthesis, characterization, dynamics and reactivity toward amination of $\eta^{3}$-allyl palladium complexes bearing mixed ancillary ligands. Evaluation of the electronic characteristics of the ligands from kinetic data. Dalton Trans. 2011, 40, 966-981. [CrossRef] [PubMed]

30. Sha, S.-C.; Zhang, J.; Carroll, P.J.; Walsh, P.J. Raising the pKa Limit of "Soft" Nucleophiles in Palladium-Catalyzed Allylic Substitutions: Application of Diarylmethane Pronucleophiles. J. Am. Chem. Soc. 2013, 135, 17602-17609. [CrossRef] [PubMed]

31. Canovese, L.; Visentin, F.; Santo, C.; Bertolasi, V. Insertion of Isocyanides across the Pd-C Bond of

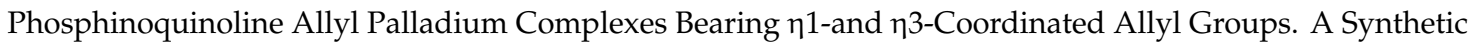
and Mechanistic Study. Organometallics 2014, 33, 1700-1709. [CrossRef]

32. Pérez, S.; López, C.; Bosque, R.; Solans, X.; Font-Bardía, M.; Roig, A.; Molins, E.; van Leeuwen, P.W.N.M.; van Strijdonck, G.P.F.; Freixa, Z. Heterodimetallic Palladium(II) Complexes with Bidentate (N,S) or Terdentate $(\mathrm{C}, \mathrm{N}, \mathrm{S})$-Ferrocenyl Ligands. The Effect of the Ligand Donor Atoms on the Regioselectivity of the Allylic Alkylation of Cinnamyl Acetate. Organometallics 2008, 27, 4288-4299. [CrossRef]

33. Platero-Prats, A.E.; Pérez, S.; López, C.; Solans, X.; Font-Bardía, M.; van Leeuwen, P.W.N.M.; van Strijdonck, G.P.F.; Freixa, Z. Palladium(II)-allyl complexes containing chiral N-donor ferrocenyl ligand. J. Organomet. Chem. 2007, 692, 4215-4226. [CrossRef]

34. Li, M.-B.; Wang, Y.; Tian, S.-K. Regioselective and Stereospecific Cross-Coupling of Primary Allylic Amines with Boronic Acids and Boronates through PalladiumCatalyzed C-N Bond Cleavage. Angew. Chem. Int. Ed. 2012, 51, 2968-2971. [CrossRef] [PubMed] 
35. Li, M.-B.; Li, H.; Wang, J.; Liu, C.-R.; Tian, S.-K. Catalytic stereospecific alkylation of malononitriles with enantioenriched primary allylic amines. Chem. Commun. 2013, 49, 8190-8192. [CrossRef] [PubMed]

36. Szafran, Z.; Pike, P.E.; Singh, M.M. Microscale Inorganic Chemistry: A Comprehensive Laboratory Experience; John Wiley \& Sons: New York, NY, USA, 1991.

37. Auburn, P.R.; Mackenzie, P.B.; Bosnich, B. Asymmetric synthesis. Asymmetric catalytic allylation using palladium chiral phosphine complexes. J. Am. Chem. Soc. 1985, 107, 2033-2046. [CrossRef]

38. Cambridge Crystallographic Data Centre (CCDC). Available online: http://www.ccdc.cam.uk/data (accessed on 20 June 2019).

39. Allen, F.H. The Cambridge Structural Database: a quarter of a million crystal structures and rising. Acta Crystallogr. Sect. B Struct. Sci. 2002, 58, 380-388. [CrossRef]

40. Simpson, P.V.; Skelton, B.W.; Brown, D.H.; Baker, M.V. Synthesis and Characterisation of Mono-and Bidentate Alkoxybenzimidazolin-2-ylidene Palladium Complexes: Interesting Solution Behaviour and Application in Catalysis. Eur. J. Inorg. Chem. 2011, 2011, 1937-1952. [CrossRef]

41. Bettucci, L.; Bianchini, C.; Filippi, J.; Lavacchi, A.; Oberhauser, W. Chemoselective Aerobic Diol Oxidation by Palladium(II)-Pyridine Catalysis. Eur. J. Inorg. Chem. 2011, 2011, 1797-1805. [CrossRef]

42. Trost, B.M. Asymmetric Allylic Alkylation, an Enabling Methodology. J. Org. Chem. 2004, 69, $5813-5837$. [CrossRef] [PubMed]

43. Colacot, T.J. A concise update on the applications of chiral ferrocenyl phosphines in homogeneous catalysis leading to organic synthesis. Chem. Rev. 2003, 103, 3101-3118. [CrossRef] [PubMed]

44. Helmchen, G.; Ernst, M.; Paradies, G. Application of allylic substitutions in natural products synthesis. Pure Appl. Chem. 2004, 76, 495-505. [CrossRef]

45. Becke, A.D. Density-functional thermochemistry. III. The role of exact exchange. J. Chem. Phys. 1993, 98, 5648-5652. [CrossRef]

46. Lee, C.; Yang, W.; Parr, R.G. Development of the Colle-Salvetti correlation-energy formula into a functional of the electron density. Phys. Rev. B 1988, 37, 785-789. [CrossRef]

47. Hay, P.J.; Wadt, W.R. Ab initio effective core potentials for molecular calculations. Potentials for K to Au including the outermost core orbitals. J. Chem. Phys. 1985, 82, 299-310. [CrossRef]

48. Frisch, M.J.; Trucks, G.W.; Schlegel, H.B.; Scuseria, G.E.; Robb, M.A.; Cheeseman, J.R.; Scalmani, G.; Barone, V.; Mennucci, B.; Petersson, G.A.; et al. Gaussian 09 (Revission B.1); Gaussian Inc.: Wallingford, CT, USA, 2010.

49. Tomasi, J.; Mennucci, B.; Cammi, R. Quantum mechanical continuum solvation models. Chem. Rev. 2005, 105, 2999-3093. [CrossRef]

50. Armarego, W.L.F.; Perrin, D.D. Purification of Laboratory Chemicals, 4th ed.; Butterworth-Heinemann: Oxford, UK, 1996.

51. Sheldrick, G.M. A short history of SHELX. Acta Crystallogr. 2008, 64, 112-122. [CrossRef]

52. Hariharan, P.C.; Pople, J.A. Influence of polarization functions on molecular-orbital hydrogenation energies. Theor. Chim. Acta 1973, 28, 213-222. [CrossRef]

53. Francl, M.M.; Petro, W.J.; Hehre, W.J.; Binkley, J.S.; Gordon, M.S.; DeFrees, D.J.; Pople, J.A. Self-Consistent Molecular Orbital Methods. 23. A polarization-type basis set for 2nd-row elements. J. Chem. Phys. 1982, 77, 3654-3665. [CrossRef]

(C) 2019 by the authors. Licensee MDPI, Basel, Switzerland. This article is an open access article distributed under the terms and conditions of the Creative Commons Attribution (CC BY) license (http://creativecommons.org/licenses/by/4.0/). 